\title{
Developmental Expression and Functional Characterization of the Potassium-Channel Subunit Kv3.1b in Parvalbumin-Containing Interneurons of the Rat Hippocampus
}

\author{
Jing Du, ${ }^{1}$ Lei Zhang, ${ }^{1}$ Michael Weiser, ${ }^{2}$ Bernardo Rudy, ${ }^{2}$ and Chris J. McBain ${ }^{1}$ \\ 1 Unit on Cellular and Synaptic Physiology, Laboratory of Cellular and Molecular Neurophysiology, National Institute of \\ Child Health and Human Development, Bethesda, Maryland 20892-4495, and 2Department of Physiology and \\ Neuroscience, New York University Medical Center, New York, New York 10016
}

The expression of the voltage-gated $\mathrm{K}^{+}$-channel subunit $\mathrm{K} v 3.1 \mathrm{~b}$ in the developing hippocampus was determined by immunoblot and immunohistochemical techniques. Kv3.1b protein was detected first at postnatal day $(P)$. The Kv3.1bimmunopositive cell number per tissue section reached a maximum at P14 and was maintained through P40. In contrast, the $\mathrm{Kv} 3.1 \mathrm{~b}$ protein content of isolated membrane vesicles in immunoblots progressively increased through P40, suggesting an increase in Kv3.1b content per cell throughout this time period. Kv3.1b protein was expressed selectively in the somata, proximal dendrites, and axons of cells lying within or near the pyramidal cell layer, consistent with their being GABAergic inhibitory interneurons. Kv3.1b was present in $\sim 80 \%$ of parvalbumin-positive interneurons. The developmental onset of Kv3.1b and parvalbumin immunoreactivity was identical. In contrast, Kv3.1b was mostly absent from the subset of somatostatin-positive inhibitory interneurons. Electrophysiological recordings were made from stratum pyramidale inter- neurons in which morphology and Kv3.1b-positive immunoreactivity were confirmed post hoc. Outward currents had voltage-dependent and biophysical properties resembling those of channels formed by Kv3.1b. The current blocked by low concentrations of 4-aminopyridine (4-AP) showed marked inactivation, suggesting that Kv3.1b may coassemble with other members of the Kv3 subfamily. In current-clamp recordings, concentrations of 4-AP that blocked the current through Kv3.1b channels allowed us tentatively to assign a role to Kv3.1b-containing channels in action-potential repolarization. These data demonstrate that $\mathrm{Kv} 3.1 \mathrm{~b}$ is regulated developmentally in a specific subpopulation of hippocampal interneurons and that channels containing this subunit may be a major determinant in imparting "fast-spiking" characteristics to these and other cells throughout the central nervous system containing the Kv3.1b subunit.

Key words: hippocampal interneurons; $K^{+}$-channel subunits; Kv3.1; GABA; parvalbumin; immunohistochemistry
Despite the wealth of data concerning the structure and function of voltage-gated $\mathrm{K}^{+}$-channel subunits, little is known concerning their developmental regulation, the molecular composition of native channels in the mammalian CNS, or the actual physiological roles they play (Jan and Jan, 1990; Pongs, 1992; Vega-Saenz de Miera et al., 1994; Gutman and Chandy, 1995). In situ hybridization and immunohistochemical techniques have demonstrated that many voltage-dependent $\mathrm{K}^{+}$channel subunits show regionspecific expression, which occurs in a cell-specific or subcellular manner, consistent with a highly specialized role for each subunit in distinct plrysiological processes.

The mRNAs of members of the Kv3 subfamily of voltage-gated $\mathrm{K}^{+}$channels are distributed selectively throughout the mammalian CNS (Vega-Saenz de Miera et al., 1994). High levels of Kv3.1b mRNA (designated Kv3.1 $\alpha$ in Perney et al., 1992) are expressed in the reticular thalamus and cerebellum and are under developmental regulation (Perney et al., 1992; Rudy et al., 1992;

Received Aug. 10, 1995; revised Oct. 10, 1995; accepted Oct. 12, 1995.

This work was supported by National Institutes of Health Grant NS30989 to B.R. We thank Dr. Vittorio Gallo for help with immunohistochemistry, Dr. Joanna Hill for help with the whole-animal perfusion, and Dr. Mark Mayer and Dr. Vittorio Gallo for critically reading this manuscript.

Correspondence should be addressed to Chris J. McBain, Unit on Cellular and Synaptic Physiology, Laboratory of Cellular and Molecular Neurophysiology, Room 5A72, Building 49, NICHD-LCMN, 49 Convent Drive, MSC 4495, Bethesda, MD 20892-4495.

Copyright 1996 Society for Neuroscience $0270-6474 / 96 / 160506-13 \$ 05.00 / 0$
Weiser et al., 1994). In the hippocampus, Kv3.1b mRNA expression occurs at low levels and has been shown to be restricted to cells tentatively identified as GABAergic inhibitory interneurons (Perncy et al., 1992; Weiser et al., 1994). Recently, Weiser et al. (1995), using immunohistochemical techniques, have confirmed that $\mathrm{Kv} 3.1 \mathrm{~b}$ protein is expressed in a selective population of parvalbumin-containing cells, tentatively identified as hippocampal interneurons.

Hippocampal inhibitory interneurons are GABA-containing local-circuit cells that mediate both feedforward and feedback inhibition of pyramidal neurons (Lacaille et al., 1989; Traub and Miles, 1991). Parvalbumin-containing interneurons belong to the class of "fast-spiking" interneurons in which cell bodies are located within or near stratum (st.) pyramidale (Kawaguchi et al., 1987; Kosaka et al., 1987). It is of interest that some parvalbuminpositive interneurons have been shown to be resistant to both ischemic damage (Schlander et al., 1988) after bilateral carotid occlusion (Tortosa and Ferrer, 1993) and electrographic seizureinduced neuronal damage (Sloviter, 1989). The actual mechanisms responsible for the selective resistance of these cells are unclear at present because little more than the basic physiological properties of these neurons has been investigated (Buhl et al., 1994a,b). With the exception of interneurons of the st. oriensalveus (Zhang and McBain, 1995a,b), no data exist concerning the developmental expression and the biophysical properties of voltage-gated $\mathrm{K}^{+}$channels on any of the other hippocampal 
interneuron populations. It is a reasonable assumption, however, that the action-potential properties and the specific firing patterns of these cells are determined, at least in part, by the complement of $\mathrm{K}^{+}$channels expressed by these cells.

In this study, we have investigated the developmental expression and the functional role of Kv3.1b subunits in an immunologically distinct subpopulation of hippocampal interneurons. Western blot analysis and immunocytochemistry were used to determine the developmental expression of Kv3.1b. Doublestaining techniques demonstrated that $\mathrm{Kv} 3.1 \mathrm{~b}$ is expressed predominantly in parvalbumin-containing cells, but not somatostatinpositive interneurons, commencing at approximately postnatal day (P) 8 . Finally, we have identified currents through native $\mathrm{K}^{+}$ channels that likely contain the Kv3.1b subunit and have identified a role for such currents in the action-potential waveform of morphologically identified and Kv3.1b-positive interneurons. The nomenclature of Shaker genes and products proposed by Chandy et al. (1991) was used throughout this article.

\section{MATERIALS AND METHODS}

$K v 3.1 b$ antibody production. Antibody production, purification, and initial characterization have been described previously (Weiser et al., 1995). Briefly, a peptide corresponding to the C-terminal sequence of the rat Kv3.1b protein (residues 567-585) (Luneau et al., 1991) was synthesized, and anti$\mathrm{Kv} 3.1 \mathrm{~b}$ antibodies were raised in rabbits and were affinity-purified by coupling to a Sulfolink Sepharose resin (Pierce, Rockford, IL).

Western blot analysis of hippocampal membrane vesicles. SpragueDawley rats aged P6-P40 were anesthetized deeply with Forane (Ohmeda, Liberty Corner, NJ). The crude membrane fractions were prepared as described previously by Sheng et al. (1992) with slight modifications. Briefly, the hippocampus was dissected and homogenized in homogenization buffer [ $20 \mathrm{~mm}$ Tris- $\mathrm{HCl}, \mathrm{pH} 7.4,0.3 \mathrm{~m}$ sucrose, $1 \mathrm{~mm}$ phenylmethanesulfonyl fluoride (PMSF), $1 \mu \mathrm{M}$ pepstatin A, and $2 \mu \mathrm{g} / \mathrm{ml}$ leupeptin] using a Dounce tissue grinder with a pestle at $4^{\circ} \mathrm{C}$. The homogenates were centrifuged at $1000 \times g$ for $10 \mathrm{~min}$ at $4^{\circ} \mathrm{C}$. The supernatants then were centrifuged at $100,000 \times \mathrm{g}$ for $1 \mathrm{hr}$ at $4^{\circ} \mathrm{C}$, and the pellets were dissolved in suspension buffer ( $20 \mathrm{~mm}$ Tris- $\mathrm{HCl}, \mathrm{pH} 7.4,1$ mM EDTA, 1 mM PMSF, $1 \mu \mathrm{M}$ pepstatin $\mathrm{A}$, and $2 \mu \mathrm{g} / \mathrm{ml}$ leupeptin). The resulting solution was centrifuged at $40,000 \times \mathrm{g}$ for $20 \mathrm{~min}$ at $4^{\circ} \mathrm{C}$. The pellets were resuspended in suspension buffer, and aliquots were used immediately or stored at $-80^{\circ} \mathrm{C}$ for later use. Protein concentrations were determined by Bio-Rad protein assay (Hercules, CA) according to the manufacturer's instructions with bovine serum albumin (BSA) as a control. Fifty micrograms of membrane protein were resuspended in equal amounts of sample buffer (100 mM Tris, pH 7.6, 1\% SDS, $10 \%$ glycerol, $0.05 \%$ bromphenol blue, $5 \% \beta$-mercaptoethanol), denatured at $37^{\circ} \mathrm{C}$ for $1 \mathrm{hr}$, and separated by $8 \%$ SDS-PAGE. Proteins then were transferred to nitrocellulose membranes in a transfer tank containing $25 \mathrm{mM}$ Tris, $0.2 \mathrm{M}$ glycine, and $20 \%$ methanol at $150 \mathrm{~mA}$ for $17 \mathrm{hr}$ at room temperature. Blocking of nonspecific binding was achieved by incubating the nitrocellulose membrane with Trisbuffered saline/Tween-20 (TBST; $20 \mathrm{~mm}$ Tris, pH 7.6, $137 \mathrm{mM} \mathrm{NaCl}, 0.2 \%$ Tween-20) with $5 \%$ nonfat dry milk. The blots were probed with antiKv3.1b antibody (1:3000) in TBST with $1 \%$ nonfat dry milk for 1 hr at room temperature. The secondary antibody was peroxidase-conjugated goat anti-rabbit antibody $(1: 1000)$. Enhanced chemiluminescence (ECL) was used as a secondary detection system according to the manufacturer's instructions.

$\mathrm{K}^{+}$-channel $\mathrm{Kv} 3.1 \mathrm{~b}$ immunostaining. For the developmental study of the $\mathrm{K}^{+}$-channel subunit $\mathrm{Kv} 3.1 \mathrm{~b}$ or parvalbumin immunoreactivity, $\mathrm{P} 6-\mathrm{P} 40$ animals were anesthetized deeply using Forane. The brain tissue was dissected free, and fresh-frozen tissue sections $(12 \mu \mathrm{m})$ were processed commercially by American Histolab (Gaithersburg, MD). The freshfrozen sections were allowed to come to room temperature before fixation in $4 \% p$-formaldehyde in PBS for $5 \mathrm{~min}$ on ice. The sections were then washed with PBS once and taken through an alcohol series $(50,70$, and $95 \%$ ) before being stored in $95 \%$ alcohol at $4^{\circ} \mathrm{C}$ until needed. The tissue sections were rehydrated with an alcohol series $(90,70$, and $50 \%)$ and PBS for 5 min each. They then were incubated in $0.3 \% \mathrm{H}_{2} \mathrm{O}_{2}$ in methanol for $3 \mathrm{~min}$ to remove endogenous peroxidase activity. After washing three times in PBS, a 30 min immersion in $0.2 \%$ Triton X-100 and $1 \%$ BSA in PBS was followed by overnight incubation with rabbit
anti-Kv3.1b (1:3000) in 0.5\% BSA in PBS. All incubations and wash stcps were performed in $0.5 \%$ BSA in PBS. For the secondary antibody, biotinylated goat anti-rabbit antibody (1:200) was added for $1 \mathrm{hr}$, followed by an incubation with horseradish peroxidase (HRP)-avidinbiotin complex (1:50, Vector Elite ABC kit, Burlingame, CA) for an additional $1 \mathrm{hr}$. The color was developed by treatment with $0.05 \%$ diaminobenzidine (DAB) and $0.003 \% \mathrm{H}_{2} \mathrm{O}_{2}$ in PBS. The sections then were dehydrated, cleared, and mounted before photomicroscopy. The Kv3.1b-positive cell number per section was counted under microscope for later analysis. A cell was considered $\mathrm{Kv} 3.1 \mathrm{~b}$-positive if the soma and proximal dendrites were appreciably darker than the surrounding tissue when observed under high-power magnification.

Double staining of parvalbumin, somatostatin, and Kv3.1b. For the experiments involving double immunostaining with parvalbumin or somatostatin and Kv3.1b, P6-P20 animals were anesthelized willı Forane and perfused transcardially with ice-cold PBS followed by ice-cold $4 \%$ $p$-formaldehyde in PBS for $10 \mathrm{~min}$. The animals were decapitated and post-fixed overnight in $4 \% p$-formaldehyde in PBS at $4^{\circ} \mathrm{C}$. The brains were dissected from the skull and stored in $5 \%$ sucrose in PBS at $4^{\circ} \mathrm{C}$ until needed. Serial sagittal sections $(20 \mu \mathrm{m})$ of the middle portion of the hippocampus were cut on a freezing microtome (Zeiss, Jena, Germany). Sections were mounted onto gelatin coated-slides and air-dried. Sections were incubated in a blocking solution of $10 \%$ normal goat serum and $0.2 \%$ Triton X-100 in PBS for 30 min. The monoclonal antibody [mouse anti-parvalbumin (1:200) or mouse anti-somatostatin (1:10)] and rabbit polyclonal anti-Kv3.1b antibody $(1: 400)$ werc dilutcd in $5 \%$ normal goat serum in PBS and incubated with the sections overnight at $4^{\circ} \mathrm{C}$. The sections were rinsed and incubated with fluorescein isothiocyanate (FITC)-conjugated anti-mouse antibody (1:50, green stain) and Cy3conjugated goat anti-rabbit antibody (1:300, red stain) in 5\% normal goat serum in PBS for $1.5 \mathrm{hr}$ at room temperature. The sections then were rinsed, mounted, and observed by using fluorescence microscopy with the appropriate filters.

Whole-cell recordings from visually identified interneurons in hippocampal slices. Hippocampal slices were prepared as described previously (McBain, 1994). Briefly, Sprague-Dawley P14-P18 rats were killed by decapitation after deep anesthesia using Forane. The brain was removed rapidly and placed in ice-cold artificial CSF (ACSF) (in mM): $130 \mathrm{NaCl}$, $24 \mathrm{NaHCO}_{3}, 3.5 \mathrm{KCl}, 1.25 \mathrm{NaH}_{2} \mathrm{PO}_{4}, 1.5 \mathrm{CaCl}_{2}, 1.5 \mathrm{MgSO}_{4}$, and 10 glucose saturated with $95 \% \mathrm{O}_{2} / 5 \% \mathrm{CO}_{2}, \mathrm{pH} 7.4,307$ m Osm. Sagitlal slices (250- to $350-\mu \mathrm{m}$-thick) were cut from the middle third of the hippocampus using a Vibratome (Oxford series 1000, Polysciences, Warrington, PA). Slices were allowed a recovery period of $45 \mathrm{~min}$ before use, during which they were held in oxygenated media at $27^{\circ} \mathrm{C}$. During recording, slices were bathed in a tissue chamber of $1 \mathrm{ml}$ capacity and perfused at a rate of $2-4 \mathrm{ml} / \mathrm{min}$ with ACSF at room temperature $\left(24-26^{\circ} \mathrm{C}\right)$. For electrophysiological recordings, $\mathrm{Ca}^{2+}$ was omitted and $\mathrm{Co}^{2+}(1.5 \mathrm{~mm})$ was added to the recording solution to remove any $\mathrm{Ca}^{2+}$-dependent components of the outward current. Tetrodotoxin $(0.5-$ $1.0 \mu \mathrm{M})$ and the AMPA-receptor antagonist 6,7-dinitroquinoxaline-2,3dione $(20 \mu \mathrm{M})$ were added to the perfusate to block voltagc-dependent sodium channels and excitatory synaptic activity, respectively. All drugs were applied in known concentrations by direct addition to the perfusate via a three-way tap.

Tight-seal $(>1 \mathrm{G} \Omega$ ), whole-cell recordings (Hamill et al., 1981; Edwards et al., 1989) were obtained from the cell bodies of interneurons located at the border between st. pyramidale and st. oriens or radiatum. The cell bodies of these cells were resolved easily and were identified tentatively as interneurons before confirmation by post hoc biocytin processing. Electrodes were fabricated from borosilicate glass and were not fire-polished. Patch electrodes had resistances of 3-6 $\mathrm{M} \Omega$ when filled with (in mM): $130 \mathrm{~K}$-gluconate, $10 \mathrm{NaCl}, 2 \mathrm{Na}_{2}$-ATP, $0.3 \mathrm{Na}$-GTP, 10 HEPES, 0.6 EGTA, 1 tetraethylammonium (TEA), 5 glutathione, buffered to $\mathrm{pH} 7.4$ and $\sim 275 \mathrm{mOsm}$. Biocytin $(0.4 \%)$ was added to the internal solution for post hoc histochemical study. All data are represented as mean \pm SEM. Seals were attained by the method originally described by Blanton et al. (1989). The electrode was positioned under visual control within the CA1 subfield; individual cells were visualized by using a Zeiss water-immersion objective modified with Hoffman (Nutley, NJ) optics (overall magnification $500 \times$ ). Cell sealing and breakthrough to whole-cell mode were performed under current-clamp conditions to allow an initial evaluation of cell viability. The series resistance usually ranged from 20 to $33 \mathrm{M} \Omega$; membrane potentials were not corrected for these errors. Linear leak current and the capacitive artifacts were subtracted digitally by using $\mathrm{P} / 4$ subtraction before data acquisition and 
analysis. All recordings were obtained with an Axopatch 1D amplifier (Axon Instruments, Foster City, CA). Records were filtered at $1-5 \mathrm{kHz}$ and digitized at $3-10 \mathrm{kHz}$ on a $486 \mathrm{PC}$. Data were acquired and analyzed using the pClamp suite of programs (Axon) and Microcal Origin (Boston, MA).

Biocytin detection and immunostaining after electrophysiological recording. After electrophysiological recording, the slice was fixed in $4 \%$ $p$-formaldehyde in PBS for $1 \mathrm{hr}$ on ice and stored in $1 \% p$-formaldehyde in PBS overnight at $4^{\circ} \mathrm{C}$. The slice was incubated in $30 \%$ sucrose in PBS for $30 \mathrm{~min}$ at room temperature and resectioned on a freezing microtome at $-70^{\circ} \mathrm{C}$ in $40-70 \mu \mathrm{m}$ sections. The sections were mounted and dried on gelatin-coated slides. Before biocytin detection, the sections were rehydrated in PBS for $10 \mathrm{~min}$ and preincubated in HEPES buffer $(10 \mathrm{~mm}$ HEPES, pH $8.5,0.15 \mathrm{M} \mathrm{NaCl}$, and $0.08 \%$ sodium azide) for $10 \mathrm{~min}$. The sections then were transferred to a solution containing fluorescenceconjugated Avidin-D (1:200) and 0.2\% Triton X-100 in HEPES buffer for $20 \mathrm{~min}$ in the dark at room temperature. The sections were washed in PBS (3 times). A 30 min immersion in $0.2 \%$ Triton X-100 and $10 \%$ normal goat serum in PBS was followed by overnight incubation with rabbit anti-Kv3.1b (1:400) in 5\% normal goat serum in PBS. After rinsing in 5\% normal goat serum in PBS ( 3 times), the sections were placed in Cy3-conjugated goat anti-rabbit antibody (1:300) in 5\% normal goat serum in PBS for $1.5 \mathrm{hr}$. They then were rinsed three times in PBS, mounted, and observed with fluorescence microscopy with appropriate filters. Cells that were filled with biocytin and were Kv3.1b-positive were photographed and drawn using camera lucida techniques to allow the complete reconstruction of the cell morphology.

Materials. The parvalbumin monoclonal antibody was obtained from Sigma (St. Louis, MO). The somatostatin monoclonal antibody was from Biomeda (Foster City, CA). The fluorescence-conjugated Avidin D, biotinylated anti-rabbit IgG, normal goat serum, and Vectastain ABC kits were from Vector. The Cy3-conjugated goat anti-rabbit antibody was from Jackson Immunoresearch (West Grove, PA). The fluorescenceconjugated anti-mouse antibody was from Cappel (Durham, NC). The peroxidase-conjugated goat anti-rabbit antibody and ECL were purchased from Amersham (Arlington Heights, IL). The molecular weight markers were purchased from Bio-Rad (Melville, NY).

\section{RESULTS}

\section{Expression of Kv3.1b in the developing hippocampus}

In situ hybridization techniques have shown previously that Kv3.1b mRNA is expressed as early as embryonic day (E) 19 in rat brain; however, a significant increase in mRNA was detected between P7 and P14 (Perney et al., 1992). In the hippocampus, only a small number of cells had grain densities greater than background levels at early stages, and only by P7 were detectable levels of Kv3.1b mRNA observed.

In the first series of experiments, we performed Western blot analysis of membrane preparations purified from the developing postnatal hippocampus. Kv3.1b protein was detected first in membrane preparations derived from P8 animals (Fig. 1). In the hippocampus, anti-Kv3.1b recognized a single, prominent band with an $M_{\mathrm{r}}$ of $\sim 96 \mathrm{kDa}$ at P8, consistent with the data obtained using the identical antibody by Weiser et al. (1995). In the present study, the mean $M_{\mathrm{r}}$ of the band recognized by the Kv3.1b antibody is $\sim 10 \mathrm{kDa}$ larger than that described for total brain by Weiser et al. (1995). The reasons for this discrepancy are unclear at present; however, this may reflect a more heavily glycosylated form of the $\mathrm{Kv} 3.1 \mathrm{~b}$ protein in the hippocampus than found in the total brain, which is dominated by the higher levels of Kv3.1b protein derived from the cerebellum compared with the small amounts of hippocampal protein. As the hippocampal developmental age progressed, the anti-Kv3.1b band on the immunoblot broadened and had an $M_{\mathrm{r}}$ ranging from 90 to $110 \mathrm{kDa}$ (Fig. 1). These data were confirmed in three independent experiments. In two experiments, densitometric measurement revealed 7.1- and 6.0-fold increases in the protein content from immunoblots obtained at P20 compared with that observed at P14.

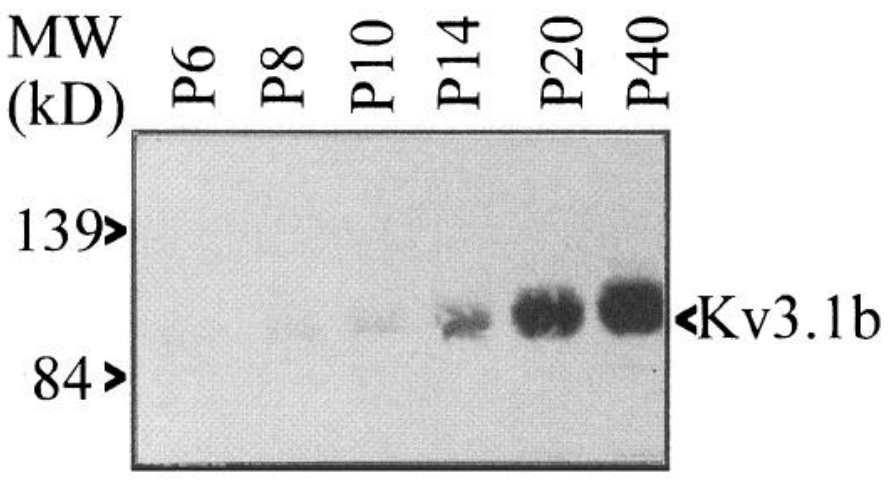

Figure 1. The developmental expression of $\mathrm{Kv} 3.1 \mathrm{~b}$ protein as detected by immunoblot analysis. Equal amounts $(50 \mu \mathrm{g})$ of protein isolated from hippocampal membrane vesicles from P6-P40 animals were fractionated on SDS-polyacrylamide gels, transferred to nitrocellulose membrane, and incubated with anti-Kv3.1b antibody $(1: 3000)$. ECL was used as a secondary-detection system. Detection of Kv3.1b protein commenced in membrane preparations isolated from P8 animals and was detected as a prominent band ranging from 90 to $110 \mathrm{kDa}$. The Kv3.1 protein content was observed to increase continuously through P40, the oldest age tested. These data were confirmed in three independent experiments.

Despite the previous observation that Kv3.1b mRNA was detected first at E19 in total rat brain, we were unable to detect $\mathrm{Kv} 3.1 \mathrm{~b}$ protein in hippocampal membrane tissue derived before P8. Because Kv3.1b mRNA has been shown to be expressed only in a selective subpopulation of neurons of the hippocampus, we considered it possible that the amount of Kv3.1b protein extracted from younger tissue was low compared with the total amount of protein derived from the principal pyramidal neurons, which outnumber these interneurons by at least 10 -fold. Next, to determine whether Kv3.1b was expressed in any cell type in younger hippocampus, we performed immunohistochemical detection on tissue sections derived from $\mathrm{P} 0-\mathrm{P} 40$ rat brains.

$\mathrm{Kv} 3.1 \mathrm{~b}$ protein expression was not detected in hippocampal tissue derived at P0, P6, and P7 ( $n=4$; data not shown). At P8, a few nonpyramidal cells located at the borders between strata radiatum and pyramidale and strata oriens and pyramidale were Kv3.1b-immunopositive (Fig. 2A). At P14 and P20, there was a marked increase in the number of cells that were Kv3.1bimmunopositive ( 1 tissue section from each animal; $n=4$ animals). In general, these cells were found throughout all hippocampal subfields from the hilus to the subiculum.

Figure $2 B$ shows high-power images of Kv3.1b-positive cells in tissue derived from P14 animals. In the CA1 and CA3 subfields, Kv3.1b-positive cells usually lay at the border between st. pyramidale or st. oriens. Occasionally, cells were found deep in the st. pyramidale proper. Kv3.1b-positive cells rarely were observed in the st. lucidum and lacunosum-moleculare. The anatomical localization of these Kv3.1b-positive cells is consistent with their being GABAergic inhibitory interneurons (Buhl et al., 1994a,b). In the dentate gyrus, on the basis of their positioning at the border of the granule cell layer, the Kv3.1b-positive cells likely were inhibitory basket cells. The granule cells of the dentate gyrus did not appear to express $\mathrm{Kv} 3.1 \mathrm{~b}$ at high levels. Kv3.1b protein was restricted primarily to the somata and the proximal dendrites of positive cells, and only extremely rarely were we able to observe Kv3.1b immunostaining on the distal dendrites of these cells (see Fig. 2B). Of interest, we were always able to distinguish Kv3.1b staining above background in the pyramidal cell layer (see P20 in Fig. 2 and fluorescent images in Fig. 6). This staining clearly was not in 

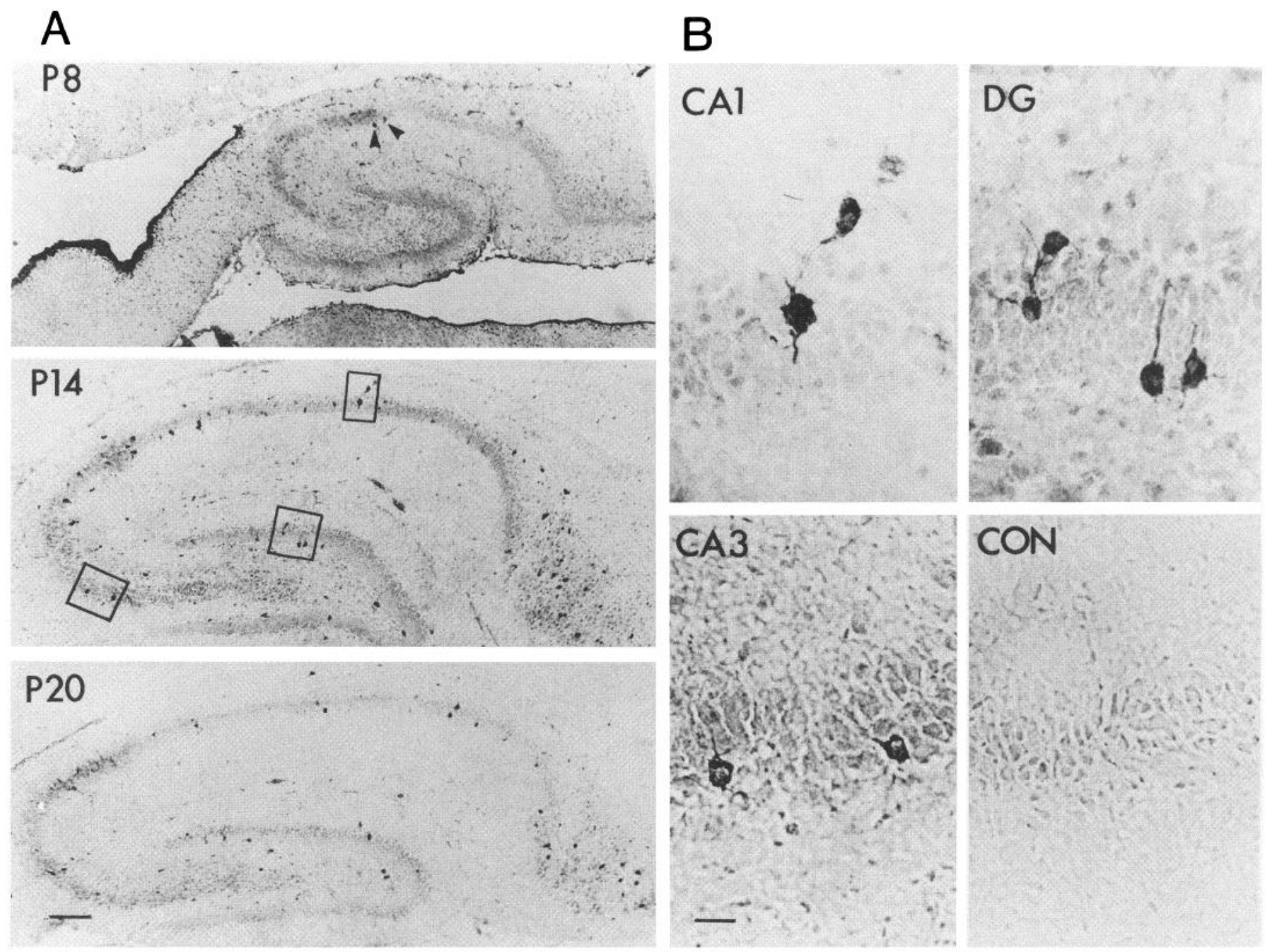

Figure 2. The developmental distribution of $\mathrm{Kv} 3.1 \mathrm{~b}$ in tissue sections of the hippocampus. Low-power $(34 \times)$ bright-field photomicroscopy of hippocampal sections $(12 \mu \mathrm{m})$ from P8, P14, and P20 animals $(A)$ that were immunostained with anti-Kv3.1b antibody $(1: 3000)$. The secondary antibody was biotinylated goat anti-rabbit antibody (1:200). The sections were incubated with HRP-avidin-biotin complex to amplify the signal using DAB (0.05\%) as the chromogen. Consistent with data obtained from immunoblot experiments, Kv3.1b immunoreactivity was detected first in tissue derived from P8 animals. In this section, two cells located at the border of the st. pyramidale and st. radiatum were Kv3.1b-immunoreactive (filled arrowheads). By P14, numerous cells located throughont the entire hippocampus and dentate gyrus are Kv3.1b-positive. In the hippocampus proper, cells were restricted primarily to the borders between st. pyramidale and strata oriens and radiatum. A large fraction of Kv3.1b-positive cells also was identified in the subicular and hilar regions. Note the distinct absence of Kv3.1b-positive cells in the principal cell layers of st. pyramidale and the dentate gyrus. However, a diffuse band of $\mathrm{Kv} 3.1 \mathrm{~b}$ immunoreactivity could be detected in the st. pyramidale of CA3-CA1, which is consistent with the presence of Kv3.1b immunoreactivity in the axons of these cells. This pattern of Kv3.1b immunoreactivity was identical in tissue derived from P20 animals. B, Higher-power (333 $\times$ ) photomicrographs from boxes indicated in $A$ of the st. pyramidale of CA1 and CA 3 and the dentate gyrus $(D G)$ show that the Kv3.1b immunostaining is restricted primarily to the somata and proximal dendrites of these cells. The control photomicrograph $(C O N)$ depicts an identical experiment performed in the absence of primary antibody to demonstrate the specificity of the Kv3.1b antibody. Scale bars: $A, 200 \mu \mathrm{m} ; B, 20 \mu \mathrm{m}$.

the pyramidal neuron cell bodies per se; rather, it was restricted to the extracellular matrix of the pyramidal cell layer. This is evident particularly in the photomicrograph depicted in Figure 6. Because the axonal projections of this subtype of inhibitory neuron are known to be restricted to the pyramidal cell layer and the regions closely adjacent to it, it is possible that the axon projections of these cells also contain Kv3.1b immunoreactivity (Weiser et al., 1995). At this time, however, we are unable to resolve the finer axonal projections of these cells by using standard light microscopy. The use of confocal microscopic techniques will be required to resolve the immunoreactivity of the interneuron axons. The somatodendritic immunostaining pattern of the $\mathrm{Kv} 3.1 \mathrm{~b}$ antibody was consistent even when concentrations of antibody of up to
1:100 were used, suggesting that poor penetration of the antibody is not responsible for the observation that $\mathrm{Kv} 3.1 \mathrm{~b}$ is restricted to the soma and proximal dendrites of these cells. At this higher concentration of antibody, we were unable to resolve immunostaining of the distal portions of the dendritic tree further. It was observed often at higher concentrations of antibody, however, that the staining within the pyramidal cell layer was more intense, which is consistent with the heavier staining of the axonal projections of the Kv3.1b-positive interneurons. On no occasion were glial cells found to be Kv3.1b-positive. These data support and extend the recent findings of Weiser et al. (1995).

In an attempt to quantify the developmental expression of $\mathrm{Kv} 3.1 \mathrm{~b}$ in cells throughout the hippocampus, we counted the 

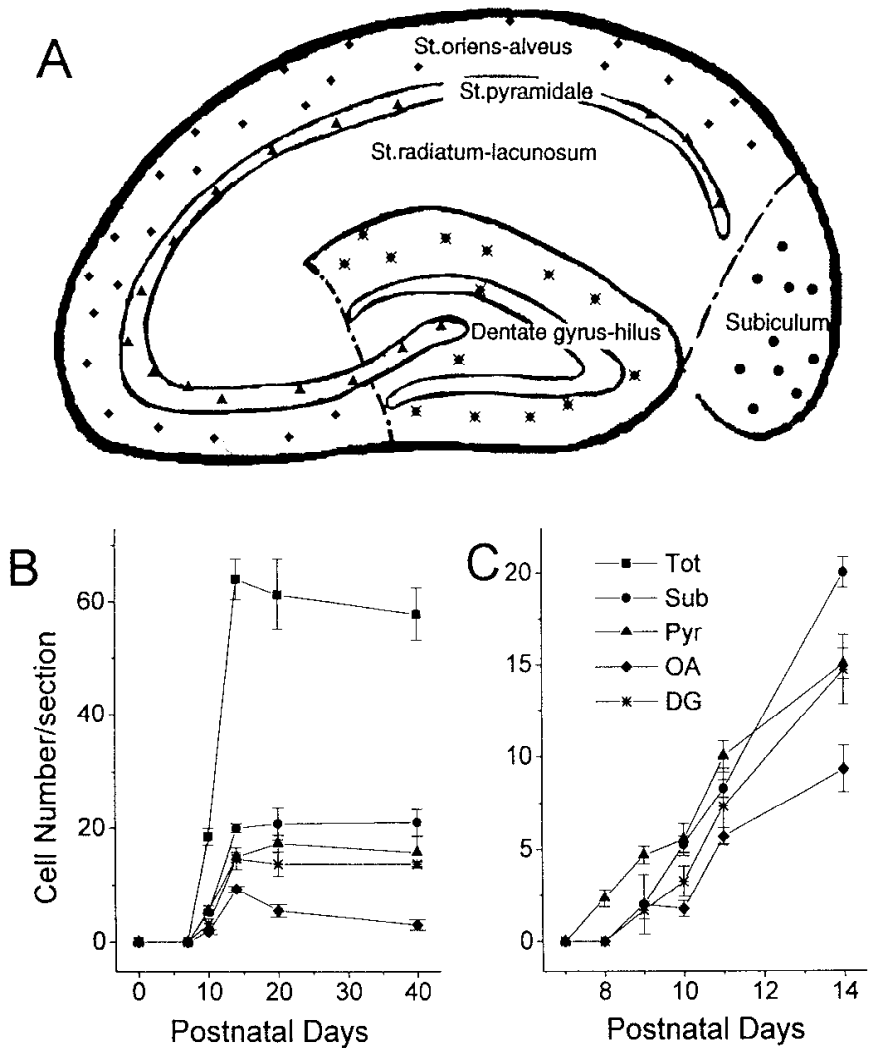

Figure 3. A schematic representation of the developmental time course of Kv3.1b-immunoreactive cell number across various regions in rat hippocampus. 'To characterize the region-specific localization of hippocampal Kv3.1b-positive cells, we divided the hippocampus into four principal regions as depicted in $A$ : st. oriens-alveus (St.oriens-alveus), st. pyramidale (St.pyramidale), Subiculum, and Dentate gyrus-hilus. Kv3.1b immunostaining was performed on hippocampal sections derived from four animals from two litters at each age (P6, P7, P8, P9, P10, P11, P14, P20, and P40). The cell number per section was counted and is represented graphically in $B$. Data are presented as mean \pm SE $(n=4)$. The developmental onset of $\mathrm{Kv} 3.1 \mathrm{~b}$ immunoreactivity progressed in parallel throughout each region of the hippocampus. Of interest, $\mathrm{Kv} 3.1 \mathrm{~b}$ was maintained in all regions between P14 and P40 except the st. oriens-alveus, in which a significant drop in the expression was observed over this tine period. By P40, the highest numbers of Kv3.1b-positive cells were found as follows: subiculum (34\%) $>$ st. pyramidale $(28 \%)>$ dentate gyrus $(22 \%)>$ st. oriens-alveus $(9 \%)$. C, To determine whether the onset of Kv3.1b immunoreactivity was identical in each region, we repeated the experiment using tissue sections derived from animals of the same litter at $24 \mathrm{hr}$ time points between P7 and P14 ( $n=4$ experiments). Kv3.1b expression started at approximately P8 in st. pyramidale and was followed closely in all subfields by P9. The Kv3.1b immunoreactivity progressively increased through P14. Sub, Subiculum; Pyr, st. pyramidale; $D G$, dentate gyrus; $O A$, st. oriens-alveus; Tot, total.

number of cells observed per section in the subfields of the dentate gyrus proper, the st. oriens-alveus region of CA3-CA1, st. pyramidale, and its borders with the strata radiatum and oriens and the subiculum. Figure $3 A$ shows the divisions of the hippocampal subfields used. In data obtained from four experiments, the highest number of Kv3.1b-positive cells was observed in the subiculum $(33.8 \pm 2.0 \%$ ), followed by cells at the borders of CA1 and CA3 st. pyramidale $(28.2 \pm 0.8 \%)$ and the dentate gyrus $(22.4$ $\pm 1.8 \%$; Fig. $3 B$ ). In contrast, only a small number of cells was detected in the subfields of st. oriens-alveus $(9.4 \pm 2.1 \%)$ and st. lacunosum-moleculare $(6.5 \pm 1.6 \%)$. Our data show a close correlation with the distribution of $3.1 \mathrm{~b}$ mRNA and protein described by Weiser et al. $(1994,1995)$.
It should be noted that despite the different absolute numbers of cells per subfield, the onset of $\mathrm{Kv} 3.1 \mathrm{~b}$ expression occurred primarily around P8 in all subfields (Fig. 3). Because there appeared to be an abrupt change in the number of cells expressing Kv3.1b between P8 and P14, we repeated this experiment using daily time points on tissue derived from P7-P14 littermates $(n=$ 4) to determine a finer pattern of developmental expression. This experiment revealed that the expression of $\mathrm{Kv} 3.1 \mathrm{~b}$ increased up to P14 (Fig. 3B). After P14, the number of Kv3.1b-positive cells remained constant up to $\mathrm{P} 40$ (the oldest age tested) in all subfields with the exception of the st. oriens-alveus, in which there was a small but significant decrease in the number of Kv3.1b-positive cells (Fig. 3B). Interestingly, despite the observation that the number of cells expressing Kv3.1b remains constant after P14, the data obtained from Western blot analysis (Fig. 1) clearly show that the Kv3.1b protein content of the hippocampus continues to increase over this period (an approximatcly sixfold increasc bctween P14 and P20 tissue). The most parsimonious explanation for this observation is that the membrane surface area of the axon and dendritic processes of these Kv3.1b-containing interneurons continue to develop over this period, allowing the insertion of greater amounts of $\mathrm{Kv} 3.1 \mathrm{~b}$ protein per cell or, alternatively, that for a constant membrane surface area the channel density is greater. It is unlikely that the discrepancy between constant cell number and the continued increase in Kv3.1b protein levels is attributable to the developmental changes in the hippocampal volume "diluting" the cell number observed per tissue section. Although the increase in $\mathrm{Kv} 3.1 \mathrm{~b}$-positive cells reaches a maximum by P14, the volume of the hippocampus develops linearly between P7 and P21 ( 10\%/d) (Bayer, 1980b), suggesting that changes in hippocampal volume and positive cell number per section are unrelated.

\section{Colocalization of Kv3.1b with parvalbumin-containing but not somatostatin-containing, interneurons}

The distribution of Kv3.1b-containing neurons suggests that these cells correspond to a particular subset of hippocampal inhibitory interneurons. Differentiation and identification of particular subsets of GABAergic inhibitory neurons have been demonstrated using the cell-specific detection of a variety of neuropeptides or calcium-binding proteins in these cells (Morrison et al., 1983; Nunzi et al., 1985; Katsumaru et al., 1988; Gulyas et al., 1992). In both the hippocampus and the striatum, Kv3.1b has been shown to colocalize in cells predominantly expressing the calcium-binding protein parvalbumin (Lenz et al., 1994; Weiser et al., 1995). These experiments, however, did not address whether Kv3.1b was colocalized with other markers for other classes of inhibitory interneurons. In the hippocampus, parvalbumin-containing interneurons have a roughly similar distribution to that of those cells shown to be Kv3.1b-positive (Sloviter, 1989). In contrast, somatostatin is known to label a different subset of interneurons from those known to express parvalbumin (Sloviter, 1989; Nitsch et al., 1990a,b; Bergmann et al., 1991). Therefore, we chose to perform double immunohistochemistry using antibodies against either somatostatin or parvalbumin with anti-Kv3.1b (2-3 tissue sections/ experiment; $n=2$ ). Figure $4 \mathrm{~A}$ demonstrates that in $\mathrm{P} 20$ hippocampus Kv3.1b is coexpressed with parvalbumin. At P20, 82\% of all cells containing parvalbumin were Kv3.1b-positive (Fig. 4Aii). Furthermore, $>90 \%$ of Kv3.1b-positive cells were parvalbumin-positive. In contrast, somatostatin preferentially labeled a distinct subset of interneurons from those that were parvalbumin-positive. As demonstrated previously, somatostatincontaining interneurons were restricted primarily to the st. oriens- 

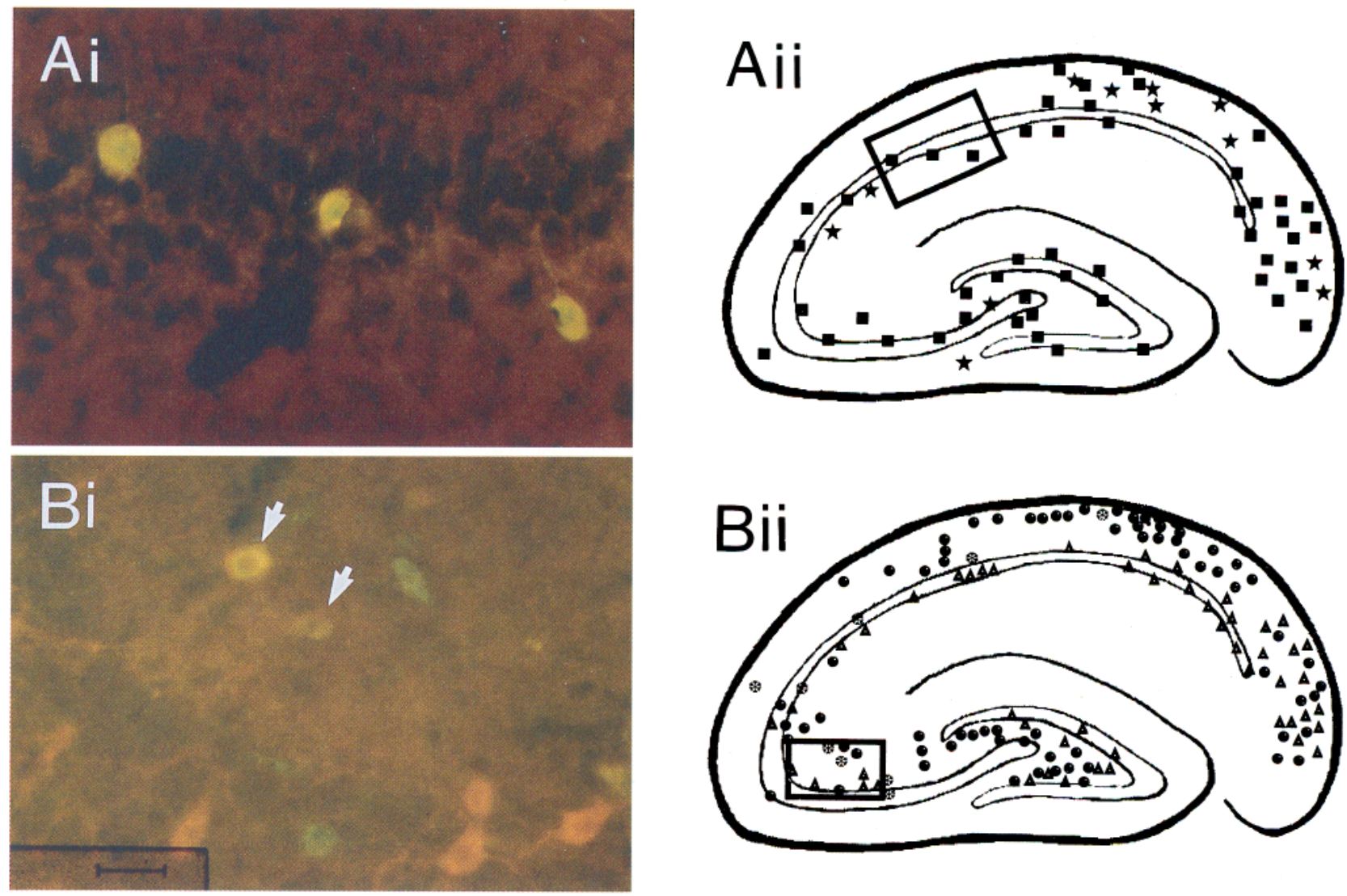

Figure 4. Kv3.1b colocalizes with parvalbumin, but not somatostatin, in distinct populations of hippocampal interneurons. Double immunostaining was performed on tissue sections derived from P20 animals to determine whether Kv3.1b colocalized with the calcium-binding protein parvalbumin or with somatostatin, markers for distinct subsets of hippocampal interneurons. The secondary antibodies were fluorescence-conjugated anti-mouse antibodies for parvalbumin and somatostatin (1:50, green) and Cy3-conjugated goat anti-rabbit antibody for Kv3.1b (1:300, red). Sections were observed by using fluorescence microscopy with the appropriate filters. $A, \mathrm{Kv} 3.1 \mathrm{~b}$ is expressed in parvalbumin-containing cells. In this double exposure, cells that were immunopositive for both Kv3.1b (red) and parvalbumin (green) appear yellow (magnification $250 \times$ ). Note the absence of immunoreactivity for either marker in the st. pyramidale. Aii, Schematic representation of double immunostaining with parvalbumin and Kv3.1b antibodies in hippocampal sections. Cells that were immunopositive for both parvalbumin and Kv3.1b are depicted by solid squares. Approximately $80 \%$ of all cells containing parvalbumin also were Kv3.1b-positive. The remaining cells were parvalbumin-positive only (stars); $100 \%$ of the Kv3.1-positive cells also were parvalbumin-positive. Cells surrounded by the rectangle in Aii are the cells depicted in Ai. B, Kv3.1b is expressed in only a very small percentage of somatostatin-positive cells. $B i$, Double immunostaining with somatostatin (green) and Kv3.1b (red) reveals little overlap in the cells containing either Kv3.1b or somatostatin (magnification $200 \times$ ). In this panel and in the schematic representation of this experiment (Bii), Kv3.1b was observed to colocalize with somatostatin in $\sim 5 \%$ of somatostatin-positive cells (yellow cells marked by white arrowheads in Bi). Bii, Schematic representation of the distributions of Kv3.1b-positive cells (triangles), somatostatin-positive cells (solid circles), and cells containing positive signals for both markers (hatched circles). Note the nearly distinct pattern of distribution of Kv3.1b cells compared with somatostatin-positive cells. Scale bars: $A i, 30 \mu \mathrm{m} ; B i, 40 \mu \mathrm{m}$.

alveus and the hilar subfield (Bakst et al., 1985; Kohler and Chan-Palay, 1982). A small number of somatostatin cells $(<10 \%)$, however, were Kv3.1b-positive (Fig. 4B). These Kv3.1b- and somatostatin-positive neurons typically were found near the st. pyramidale and, particularly in CA3, which is similar to the distribution of parvalbumin-positive cells. Previous studies have shown that a small number of parvalbumin-positive hippocampal interneurons $(\sim 12 \%)$ also contains somatostatin immunoreactivity (Van der Zee and Luiten, 1993). These data demonstrate that a vast majority of cells containing Kv3.1b were parvalbuminpositive and primarily somatostatin-negative; however, a small number of somatostatin-containing inhibitory neurons also expressed $\mathrm{Kv} 3.1 \mathrm{~b}$, which is consistent with a small overlap between parvalbumin and somatostatin immunoreactivity.

\section{Kv3.1b and parvalbumin show identical developmental expression in interneurons}

Inhibitory interneurons of the hippocampus are known to be generated prenatally (Bayer, 1980a; Amaral and Kurz, 1985; Lub- bers et al., 1985; Soriano et al., 1989) and to establish symmetric GABAergic synapses on the principal neurons around P5 (Seress et al., 1989). In the hippocampus, parvalbumin-positive immunoreactivity, however, appears around $\mathrm{P} 7-\mathrm{P} 9$, indicating a relatively late postnatal neurochemical maturation of this subpopulation of cells (Nitsch et al., 1990a; Bergmann et al., 1991). These studies have shown a sequential neurochemical and morphological maturation of parvalbumin-positive inhibitory neurons, which likely is related to the maturation of inhibition during hippocampal development. Because Kv3.1b-positive cells were not detectable until the second week of postnatal life, we wanted to determine the developmental expression pattern of parvalbumin immunoreactivity compared with the expression pattern of Kv3.1b. In these experiments, the developmental colocalization of both parvalbumin and Kv3.1b was studied using tissue slices derived from P6, P8, P10, and P14 animals of the same litter $(n=2)$. Of interest, the commencement of parvalbumin expression was coincident with Kv3.1b expression. Both parvalbumin- and Kv3.1b- 

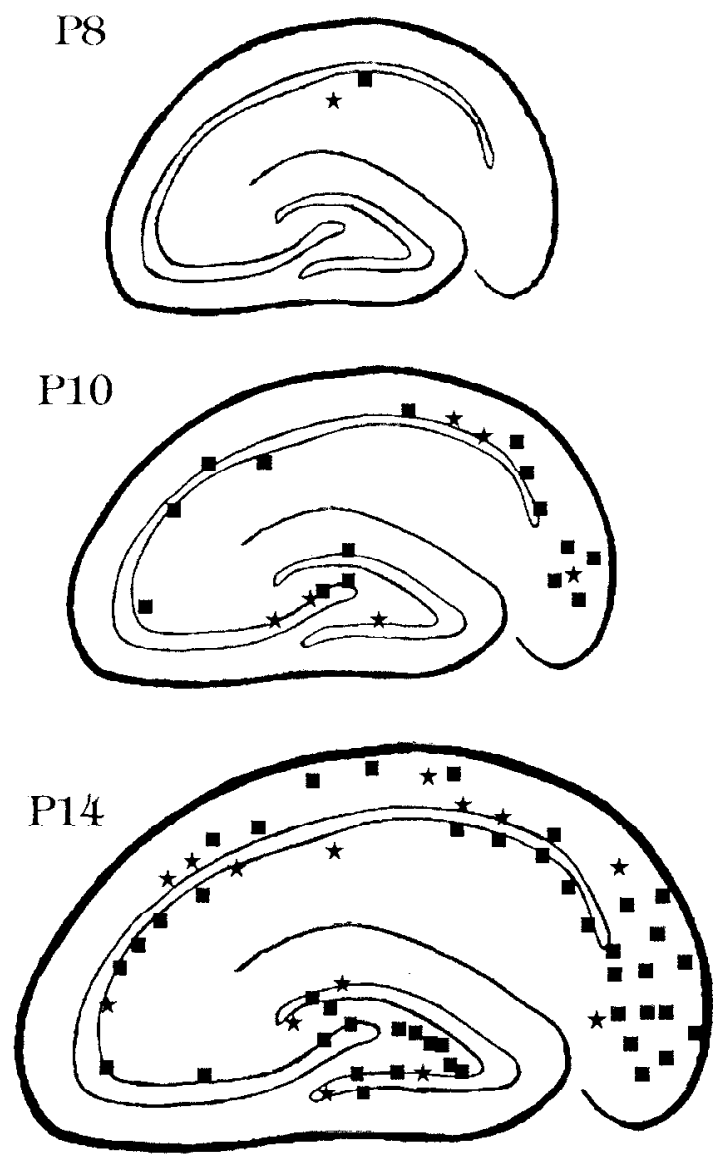

Figure 5. The developmental onset of parvalbumin immunoreactivity coincides with expression of $\mathrm{Kv} 3.1 \mathrm{~b}$ in rat hippocampus. Schematic representation of the results of double-immunostaining experiments to determine the developmental onset of parvalbumin immunoreactivity and the expression of the Kv3.1b subunit. The double staining of parvalbumin and Kv3.1b was performed as described in Figure 4 using hippocampal sections derived from P8, P10, and P14 animals. The onset of parvalbumin immunoreactivity is coincident with the expression of $\mathrm{Kv} 3.1 \mathrm{~b}$ in hippocampal interneurons in P8 animals. In all schematic diagrams, cells that were positive for both parvalbumin and Kv3.1b are depicted by solid squares. Parvalbumin-positive cells that lacked $\mathrm{Kv} 3.1 \mathrm{~b}$ expression are depicted by stars. By P10 and P14, $\sim 75 \%$ of all parvalbumin positive cells also were Kv3,1b-positive.

immunoreactive cells were observed first on P8 in cells of the CA1 subfield (Fig. 5). At P10 and P14, expression of both Kv3.1b and parvalbumin was found throughout the CAl-CA4 subfields. Seventy-four percent of all parvalbumin-positive cells were Kv3.1b-positive by P10. At these postnatal stages, every cell that was Kv3.Ib positive was also parvalbumin-positive. These data demonstrate that the appearance of $\mathrm{Kv} 3.1 \mathrm{~b}$ and parvalbumin immunoreactivity is coincident, suggesting that certain physiological attributes of these cells coincide with their neurochemical maturation. Acquisition of both of these properties may play a major role in determining the postnatal development of certain forms of inhibition in the hippocampus.

\section{A functional role for $\mathrm{Kv} 3.1 \mathrm{~b}$ in parvalbumin-containing interneurons}

Despite the observation that Kv3.1b expression occurs in parvalbumin-containing interneurons, no data exist concerning the functional role, if any, played by channels formed by this $\mathrm{K}^{+}$-channel subunit. To determine whether $\mathrm{Kv} 3.1 \mathrm{~b}$ played a role in the normal physiology of parvalbumin-containing interneurons, we made whole-cell patch-clamp recordings from inhibitory neurons located at the borders of strata radiatum, oriens, and pyramidale. Hippocampal slices were made from animals between P14 and P18, a period in which the maximum number of Kv3.1bcontaining cells was observed in our developmental study. During the course of the whole-cell recordings, cells were filled with $0.4 \%$ biocytin, allowing post hoc determination of their morphology and axonal projections, thereby confirming their identity as interneurons (McBain et al., 1994). Kv3.1b immunohistochemistry then was performed to confirm the presence (or absence) of this subunit on the cell from which recordings were made. Figure 6 demonstrates the morphological and immunohistochemical data obtained from one such experiment. Figure $6 A$ (top) shows a field of Kv3.1b-positive hippocampal cells using a secondary antibody with Cy3 fluorescence (positive cells appear red). The cell indicated by the arrow is the interneuron from which the recording was made and appears yellow in Figure $6 B$ when imaged for the fluorescence of both the Cy3 (red) and fluorescein (green). The fluorescein from the FITC-conjugated Avidin-D was used as a secondary marker for biocytin. Using serial sectioning and camera lucida techniques, the entire dendritic and axonal morphology of this Kv3.1b-positive cell then was reconstructed (Fig. 6C). In all experiments in which recordings were made from cells subsequently shown to be Kv3.1b-immunopositive, cells possessed one of two types of morphologies. The predominant cell type (illustrated in Fig. $7 A ; n=7$ ) possessed a cell body located at the border of strata oriens or radiatum and st. pyramidale of CA1, and the multipolar aspiny dendritic tree extended into both strata oriens and radiatum. The axons of these cells (the finer process in the camera lucida drawing) ramified extensively throughout the pyramidal cell layer, with little of the axonal arborization occurring in st. oriens or st. radiatum, which is typical of basket-cell morphology. The second type of Kv3.1b-positive cell possessed an identical dendritic morphology, but had an axon that showed a bistratified arborization and ramified extensively on either side of st. pyramidale in strata oriens and radiatum (cell illustrated in Fig. $6 C ; n=2$ ). These morphologies are consistent with the known properties of inhibitory neurons of st. pyramidale (Buhl et al., 1994a,b).

Currents through channels formed by Kv3.1 are mostly unaffected by millimolar concentrations of internal TEA, a concentration that effectively blocks currents through many other $\mathrm{K}^{+}$. channel subunits (Taglialatela et al., 1991). During experiments using voltage-clamp protocols, therefore, we included $1 \mathrm{mM}$ TEA in the internal solution to eliminate currents through channels not containing Kv3.1 and to facilitate observation of currents through channels formed by these subunits. All data shown were collected from cells subsequently shown to be Kv3.1b-immunopositive.

In heterologous expression systems, such as Xenopus oocytes and mammalian cell lines, $\mathrm{Kv} 3.1 \mathrm{a}$ and $\mathrm{Kv} 3.1 \mathrm{~b}$ proteins produce delayed rectifier -type $\mathrm{K}^{+}$currents that are detected first when the membrane is depolarized beyond $-20 \mathrm{mV}$ (Yokoyama et al., 1989; Luneau et al., 1991; Vega-Saenz de Miera et al., 1994). Therefore, we first analyzed the maintained component of the $\mathrm{K}^{+}$ current in the Kv3.1b-positive interneurons ( 8 positives out of $>40$ recordings). Sustained outward currents were evoked from a holding potential of -40 to $-60 \mathrm{mV}$ (Fig. 7), which was chosen to prevent contamination by any transient current components (Zhang and McBain, 1995a,b). Sustained outward currents were not activated until test potentials were positive to $-20 \mathrm{mV}$. Plots of the voltage dependence of the sustained current activation 

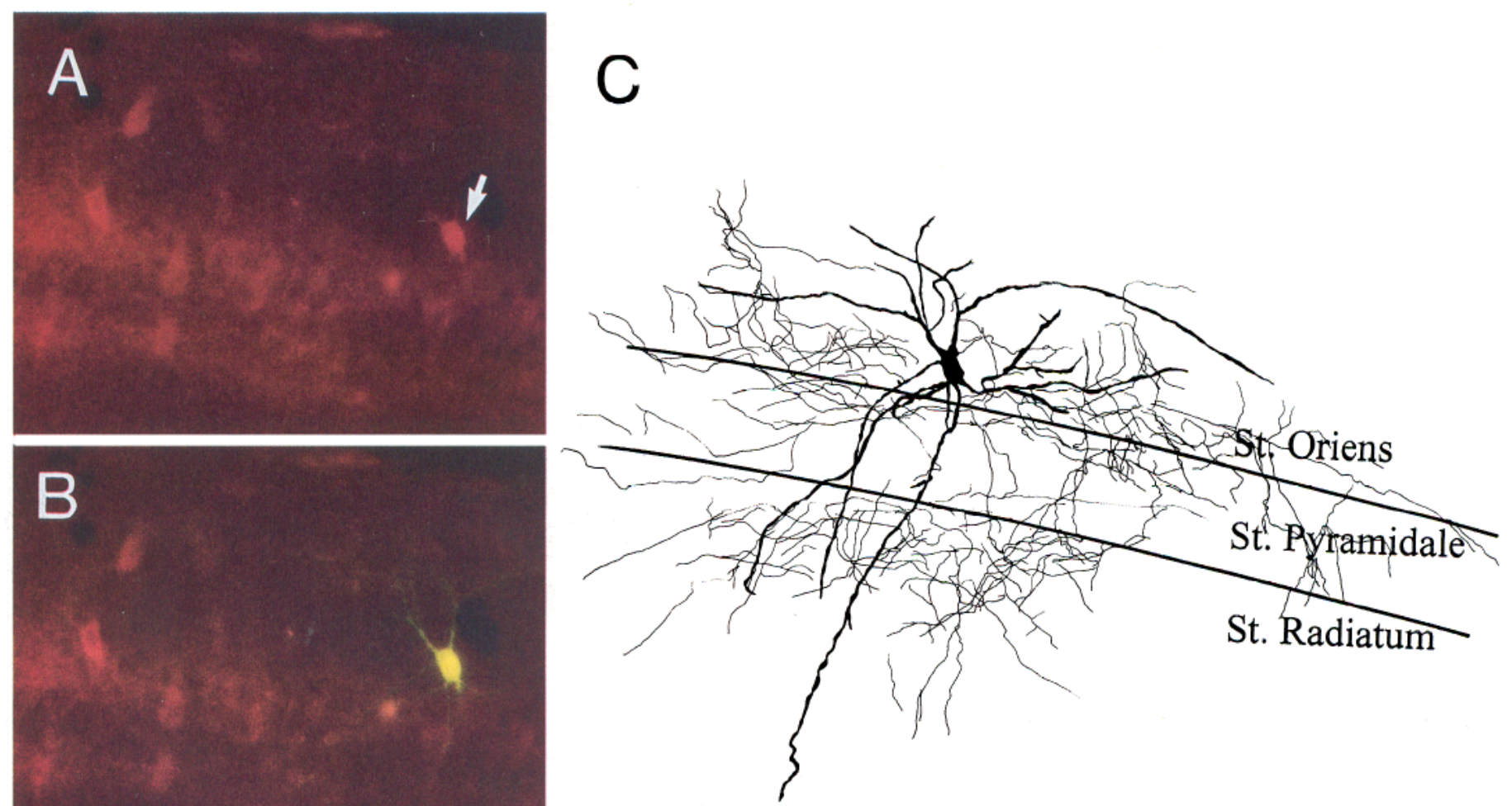

1

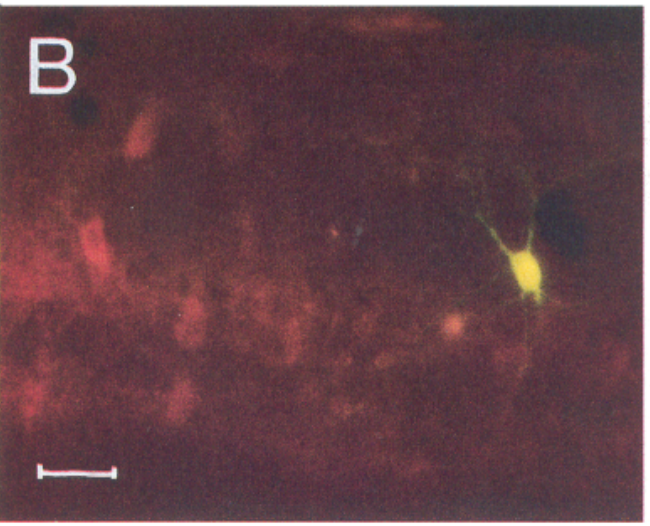

Figure 6. The morphological identification of $\mathrm{Kv} 3.1 \mathrm{~b}$-positive cells is revealed by filling with biocytin during whole-cell recording. Biocytin was introduced into inhibitory neurons by its inclusion in the internal solution used during whole-cell patch-clamp recordings. After electrophysiological characterization of individual interncurons, slices were fixed, resectioned, and processed for biocytin $(B)$ followed by the detection of Kv3.1b immunoreactivity $(A)$. This figure depicts one such successful experiment in which electrophysiology, morphology, and Kv3.1b immunoreactivity could be confirmed on a single cell. In $A$ the cell from which recordings were made is indicated by an arrowhead. It can be seen clearly using a fluorescently labeled Cy3 secondary antibody (positive cells appear red) that the cell from which the recording was made is positive for Kv3.1b. By using fluorescein-conjugated avidin-D (positive cells appear green) as a secondary marker for biocytin, the morphology of the interneuron of interest can be recovered $(B)$. The photomicrograph in $B$ is a double exposure to show both Kv3.1b immunostaining (red) and the cell from which the recording was made. The overlap of the Cy3 signal and the avidin-D signal combines to give a yellow fluorescence. $C$, Camera lucida drawing of the cell depicted in $A$ and $B$ allowed the exact reconstruction of the morphological identification of Kv3.1b-containing cells. In the illustrated cell, the soma of the interneuron lies close to the border between strata pyramidale (St. Pyramidale) and oriens (St. Oriens). The dendrites of this cell extended into both st. radiatum (St. Radiatum) and st. oriens-alveus. The fine processes represent the axonal arborization of this cell that are observed to ramify in the subfields straddling the st. pyramidale, an area containing the proximal dendrites and axons of pyramidal neurons. Scale bar, $50 \mu \mathrm{m}$.

were constructed by dividing the peak current by the current driving force $\left(V_{\text {test }}-V_{\mathrm{r}}\right)$, where $V_{\text {test }}$ is the step depolarization potential and $V_{\mathrm{r}}$ is the reversal potential. The activation profiles were fitted with a Boltzmann equation of the form:

$$
G / G_{\max }=\left[1+\exp \left\{\left(V_{\text {half }}-V\right) / V_{\mathrm{c}}\right\}\right]^{-1},
$$

where $G / G_{\max }$ is the conductance normalized to its maximum value, $V$ is the membrane potential, $V_{\text {haif }}$ is the membrane voltage at which the current amplitude is half-maximum, and $V_{c}$ is a slope factor. A fit of the data with the Boltzmann isotherm revealed a $V_{\text {haif }}$ of $+14.5 \pm 1.0 \mathrm{mV}(n=8$; Fig. $7 C)$.

A number of $\mathrm{K}^{+}$channels demonstrate cumulative inactivation during repetitive depolarizing pulses (Aldrich et al., 1979), including several heterologously expressed from cloned subunits (Grissmer et al., 1992). This use-dependent inactivation is attributable to a test pulse interval of insufficient duration to permit complete recovery from time-dependent inactivation. Homomeric channels formed by Kv3.1, however, do not demonstrate use-dependent cumulative inactivation (Grissmer et al., 1992, 1994). To determine whether any cumulative inactivation occurred in inhibitory neuron-sustained currents, we delivered repetitive test pulses to $+40 \mathrm{mV}$ at $1 \mathrm{~Hz}\left(V_{\text {hold }}=-40 \mathrm{mV}\right)$. Figure $7 D$ shows that repetitive steps to this test potential did not cause the progressive decrease of the outward current amplitude, demonstrating a lack of cumulative inactivation of the whole-cell current $(n=3)$.

Currents through channels formed by heterologous expression of members of the Kv3 subfamily are blocked by low concentrations of both external TEA $\left(\mathrm{Kv} 3.1 \mathrm{a}\right.$ and $\mathrm{Kv} 3.1 \mathrm{~b}, \mathrm{IC}_{50}=100-200$ $\mu \mathrm{M}$ ) (Yokoyama et al., 1989; Luneau et al., 1991; Grissmer et al., 1992, 1994; Vega-Saenz de Miera et al., 1994) and 4-aminopyridine (4-AP; $\mathrm{IC}_{50}=30-200 \mu \mathrm{M}$ ) (Grissmer et al., 1992, 1994; Kirsch and Drewe, 1993). This low $\mathrm{IC}_{50}$ of 4-AP for Kv3.1b makes it one of the most sensitive of all of the cloned $\mathrm{K}^{+}$-channel subunits, a property that can be used to identify currents through these channels because "native" hippocampal interneuron-delayed rectifier currents generally are insensitive to 4-AP up to high millimolar concentrations (Zhang and McBain, 1995a,b). In the next series of experiments, we determined whether any component of the sustained outward current at a test potential of $+40 \mathrm{mV}\left(V_{\text {hold }}=-40 \mathrm{mV}, 4\right.$ trials at $\left.0.1 \mathrm{~Hz}\right)$ was 
A.

Figure 7. Whole-cell recordings of outward currents from cells shown by post hoc immunohistochemistry to contain the $\mathrm{Kv} 3.1 \mathrm{~b}$ subunit. Whole-cell recordings made from Kv3.1bpositive cells $(A)$ possess outward currents that activate at potentials positive to $-20 \mathrm{mV}$. Designations as in Figure $6 \mathrm{C}$. Interneurons were voltage-clamped at $-60 \mathrm{mV}$, and families of outward currents were elicited by steps from -20 to $60 \mathrm{mV}$ (in $10 \mathrm{mV}$ increments, $200 \mathrm{msec}$ duration). Outward currents were not observed until voltages were positive to $-20 \mathrm{mV}$. C, Voltage-dependent activation curves were constructed for all cells subsequently shown to be Kv3.1b-positive. The outward currents in these cells possessed a half-activation at $+14.5 \pm$ $1.0 \mathrm{mV}(n=8) . D$, Repetitive voltage steps $(1 \mathrm{~Hz})$ to $+40 \mathrm{mV}$ reveal a lack of cumulative inactivation in cells possessing the Kv3.1b subunit. The traces depicted in $D$ show five overlapping current traces.

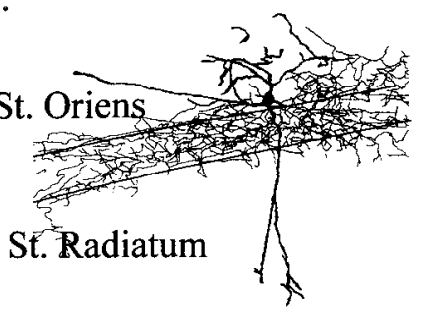

C.

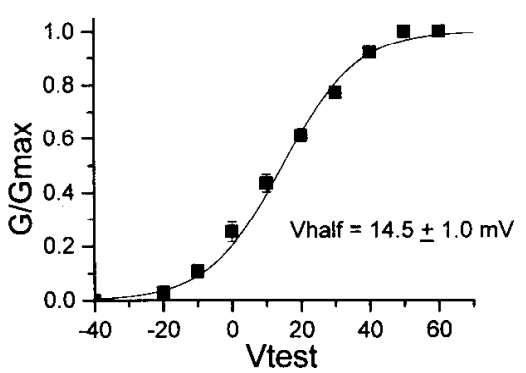

B.

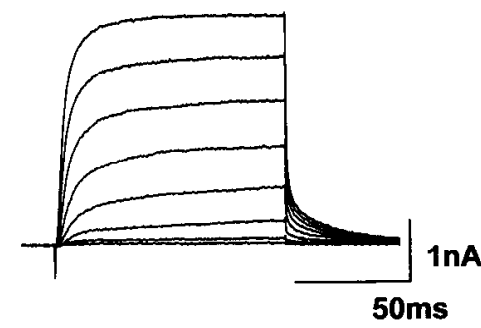

D.

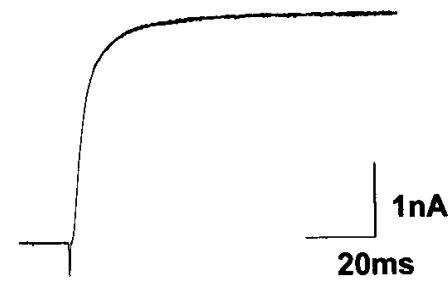

sensitive to low concentrations of 4-AP $(100 \mu \mathrm{M})$. Hippocampal slices were exposed to 4-AP for a period of 5-10 min to permit the drug concentration to reach equilibrium within the slice. In all Kv3.1b-positive cells, the sustained current possessed a component that was blocked by $100 \mu \mathrm{M}$ 4-AP. 4-AP removed a considerable fraction of the total outward current (mean $38.1 \pm 8.0 \%, n$ $=8$; Fig. $8 A$ ). Subtraction of the current remaining in 4-AP from the total current allowed the isolation of the 4-AP-sensitive current (Fig. $8 B$ ). In all cells, the current blocked by $4-A P$ at $+40 \mathrm{mV}$ was rapidly activating and had a time-to-peak of $3.9 \pm 0.4 \mathrm{msec}(n$ $=8$ ). The 4-AP-sensitive current contained a partially inactivating component for which decay was best-fit by a single exponential with a time constant of $6.9 \pm 1.5 \mathrm{msec}(n=7)$. The 4-AP-sensitive current never demonstrated complete time-dependent inactivation, even when pulses of $2 \mathrm{sec}$ duration were given (data not shown). Although the fraction of current blocked by 4-AP in any given Kv3.1b-positive cell showed a considerable range (20-90\%), the isolated 4-AP-sensitive current always had an inactivating component that was independent of the isolated current amplitude $(n=7)$. In only one cell were we able to determine the conductance-voltage $(g-V)$ relationship of the 4-AP-sensitive component. The $V_{\text {half }}$ of the $g-V$ relationships was $+12 \mathrm{mV}$ (data not shown), a value close to the $V_{\text {tralf }}$ for the total whole-cell current (+14 mV; Fig. $7 C$ ).

In cells subsequently shown to lack the Kv3.1b protein, the voltage dependence of sustained current activation also was in the positive range (mean $V_{\text {halt }}=7.7 \pm 1.3 \mathrm{mV}, n=8$; Fig. 9.A); however, 4-AP had no effect on this current component (mean reduction at $+40 \mathrm{mV}$ was $4.9 \pm 2.6 \%, n=14$; Fig. $9 B$ ). In three cells, however, which were shown subsequently to be Kv3.1bnegative, $100 \mu \mathrm{M} 4$-AP attenuated the sustained current component by $30-50 \%$. These cells, however, possessed morphologies consistent with their belonging to a distinct set of interneurons located high in st. oriens-alveus (McBain ct al., 1994), suggesting that other functional subunits of the Kv3 subfamily are expressed in different hippocampal interneuron subpopulations.

The kinetics of closure of recombinant $\mathrm{Kv} 3.1 \mathrm{~b}$ channels is extremely rapid and has been shown to deactivate with a time constant of $\sim 2 \mathrm{msec}$ at $-60 \mathrm{mV}$ (Grissmer et al., 1994). This rate of channel deactivation was found to be almost 10 -fold faster than any other $\mathrm{K}^{+}$-channel subunit current characterized in the study of Grissmer et al. (1994). In addition, in T lymphocytes, current through Kv3.1 channels has been suggested to underlie the 1-type $\mathrm{K}^{+}$channel (Grissmer et al., 1992). In these cells, the tail currents of the 1-type channel also have a very brief deactivation time constant of $\sim 1-3 \mathrm{msec}$ at $-60 \mathrm{mV}$. In the present experiments, deactivation rates of the total sustained current were determined by first opening the channels with a $200 \mathrm{msec}$ depolarizing pulse to $+40 \mathrm{mV}$ and then forcing the channels to close by repolarization with a step to $-40 \mathrm{mV}$. The resulting tail currents obtained under control conditions were best-fit by the sum of two exponentials (Fig. $8 C$ ). The mean $\tau$ values observed were $4.2 \pm 0.7$ and $26.5 \pm$ $3.8 \mathrm{msec}$, which comprised 38.3 and $61.7 \%$ of the total current, respectively $(n=5)$. Analysis of the tail currents of the isolated 4-AP-sensitive component ( $100 \mu \mathrm{M} 4-\mathrm{AP})$ of the outward current revealed currents that were best-fit by a single exponential with a time constant of $2.7 \pm 0.7 \mathrm{msec}(n=5)$, which accounted for $100 \%$ of the 4-AP-sensitive current. These data suggest that the total sustained outward current in these interneurons is comprised of two distinct current components under the present recording conditions. At a concentration of $100 \mu \mathrm{M}, 4$-AP removed a single current component possessing deactivation kinetics identical to $\mathrm{Kv} 3.1 \mathrm{~b}$. In cells that were shown post hoc to be Kv3.1b-negative, no fast-deactivating tail current component was observed $(n=9$; data not shown).

In current-clamp recordings, all cells subsequently shown to be Kv3.1b-positive possessed short-duration, fast-spiking action potentials and sustained repetitive firing, which is consistent with the known properties of interneurons of st. pyramidale (data not shown) (Buhl et al., 1994). To determine the physiological role of $\mathrm{Kv} 3.1 \mathrm{~b}$ channels in these inhibitory neurons, we next made current-clamp recordings and determined the effect of low concentrations of 4-AP on the action-potential waveform. Although the lack of selective antagonists precludes making a definitive conclusion of the role of Kv3.1b in any physiological process, we chose extremely low concentrations of 4-AP $(10-50 \mu \mathrm{M})$ that would have no effect on the transient current of interneurons of the st. oriens-alveus (A-current $\mathrm{IC}_{50}=1.8 \mathrm{~mm}$ ) (Zhang and McBain, 1995). In two cells, application of 4-AP at concentrations of 10,30 , and $50 \mu \mathrm{M}$ caused a progressive broadening of the 

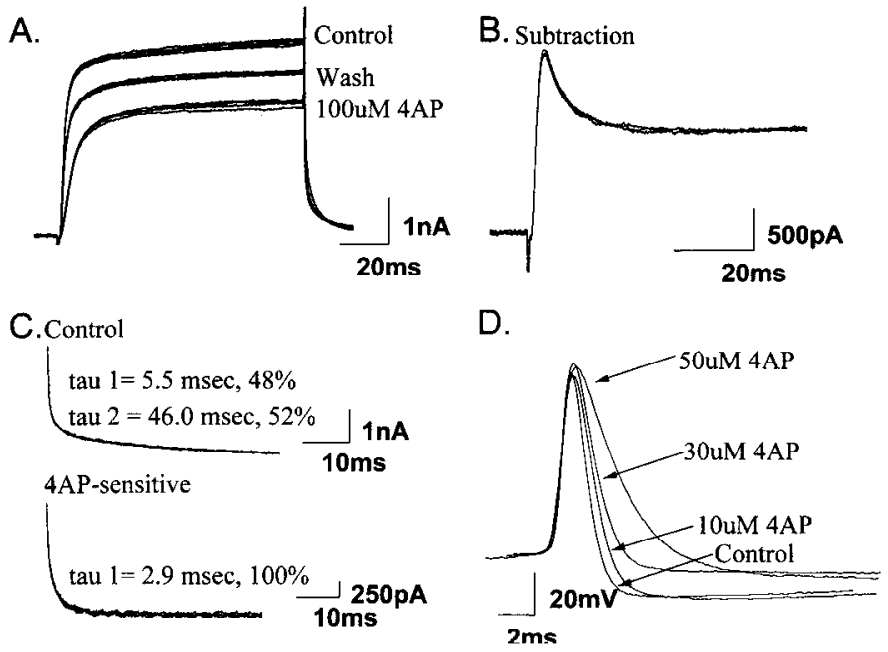

Figure 8. Low concentrations of 4-AP block an inactivating current component in Kv3.1b-positive cells. $A$, Repetitive test pulses to $+20 \mathrm{mV}$ ( $0.1 \mathrm{~Hz}, 4$ pulses in each condition) were used to evoke outward currents in Kv3.1b-positive interneurons in control conditions (Control), during 4-AP $(100 \mu \mathrm{M})$, and after 5 min of wash in drug-free solution (Wash). 4-AP blocked a significant component of the outward current that was partially reversible after return to drug-free saline. $B$, Subtraction of the current remaining in 4-AP from the control outward current revealed a rapidly activating current that partially inactivates. $B$, Four overlapping, isolated current traces obtained from the data depicted in $A$. $C$, Tail currents caused by channel deactivation were obtained by stepping back to -40 $\mathrm{mV}$ after a depolarizing test pulse to $+40 \mathrm{mV}$ for $200 \mathrm{msec}$. Tail currents obtained under control conditions were best-fit by the sum of two exponentials with time constants of 5.5 and $46.0 \mathrm{msec}$ that contributed 48 and $52 \%$, respectively, to the total current (top). Isolation of the 4-AP (100 $\mu \mathrm{M})$-sensitive current component revealed tail currents that were best-fit by a single exponential with a time constant of $2.9 \mathrm{msec}$ (bottom). $D$, Current-clamp experiments show that the repolarization phase of the action potential in Kv3.1b-positive cells is sensitive to low concentrations of 4-AP $(10-50 \mu \mathrm{M})$. At a concentration of $50 \mu \mathrm{M}$, the action-potential duration was increased by $228 \%$ of the control value. Note the augmentation of the action potential amplitude in the presence of 4-AP, which suggests that the conductance blocked by 4-AP is involved in the repolarization at the peak of the action potential.

repolarization phase of the action potential (Fig. $8 D$ ). In both cells, at a concentration of $50 \mu \mathrm{M}$, the spike width was 237 and $275 \%$ of control. Interestingly, these low concentrations of 4-AP also caused an augmentation of the peak amplitude of the action potential, which is consistent with a role for this current in the initiation of the spike repolarization. These concentrations of 4-AP had no effect on the resting membrane properties of the cell, and they did not alter the spike-firing pattern or frequency. In a single cell subsequently shown to lack the $\mathrm{Kv} 3.1 \mathrm{~b}$ protein, 4-AP $(10-50 \mu \mathrm{M})$ had only a modest effect $(<10 \%)$ on a late component of spike repolarization and had no effect on the spike amplitude (Fig. 9C). These data are consistent with a role for Kv3.1b in spike repolarization in only a select population of interneurons.

\section{DISCUSSION}

We have shown that the voltage-gated $\mathrm{K}^{+}$-channel subunit Kv3.1b is expressed developmentally in the somata, proximal dendrites, and axons of parvalbumin-containing hippocampal interneurons. Combined electrophysiological, morphological, and immunohistochemical studies in the same cell allowed us to determine both the anatomical characteristics of Kv3.1b-positive cells and a putative physiological role for Kv3.1b-containing channels.

Previous studies have shown the Kv3-family subunits to be distributed selectively throughout the CNS and to be expressed primarily by GABAergic neurons (Drewe et al., 1992; Kues and Wunder, 1992; Perney et al., 1992; Rudy et al., 1992; Lenz et al., 1994; Weiser et al., 1994, 1995; Moreno et al., 1995). Attempts to correlate current properties have shown the native current properties of these cells to possess physiological and pharmacological properties different from those of recombinant Kv3-family channels. For example, Kv3.3 is expressed strongly in cerebellar Purkinje cells, yet native currents characterized in these cells show none of the properties of either homomeric expressed Kv3.3 channels or heteromeric channels formed by Kv3.3 and other memhers of the Kv3 subfamily (Gahwiler and Ilano, 1989) (for further discussion, see Vega-Saenz de Miera et al., 1994). This observation has led to the speculation that the phenotype of Kv3-family channel-forming subunits is altered markedly during the formation of native channels by an as yet unknown mechanism. However, Grissmer et al. (1992) have proposed that the l-type voltage-dependent $\mathrm{K}^{+}$channel of $\mathrm{T}$ lymphocytes is a Kv3.1 homomultimer, because virtually all of the properties of homomerically expressed Kv3.1 are shared by the 1-type $\mathrm{K}^{+}$current. Although $\mathrm{T}$ lymphocytes exhibit only three distinct types of voltage-gated $\mathrm{K}^{+}$current, most $\mathrm{CNS}$ neurons possess a broad array of temporally overlapping currents. Thus, the identification of a particular current phenotype likely depends on the ability to "tease" apart multiple overlapping current components using a limited array of pharmacological tools. Detection of Kv3.1 pcrhaps is most amenable to this type of analysis because it possesses a high "voltage threshold" for activation $(-20 \mathrm{mV})$, a positive half-activation voltage (approximately $+15 \mathrm{mV}$ ), rapid deactivation kinetics $(\tau-2 \mathrm{msec}$ at $-60 \mathrm{mV})$, and is sensitive to low concentrations of 4-AP and TEA (Yokoyama et al., 1989; Luneau et al., 1991; Grissmer et al., 1992, 1994; Rudy et al., 1992; VegaSaenz de Miera et al., 1994; Weiser et al., 1994). In the present study, all of these features were identified in whole-cell currents obtained from a select population of inhibitory neurons located at the borders of st. pyramidale and strata oriens and radiatum. A striking feature of these interneuron currents was their halfactivation potential and the deactivation kinetics of the isolated 4-AP-sensitive current, which were virtually identical to those observed in channels formed from homomeric Kv3.1 subunits. In addition, the post hoc determination of the $\mathrm{Kv} 3.1 \mathrm{~b}$ protein in these cells lends considerable weight to the positive detection of $\mathrm{Kv} 3.1 \mathrm{~b}$-like properties in native currents in these cells.

The only striking difference between the 4-AP-sensitive current component in the present recordings and that seen in expressed recombinant Kv3.1b channels was the occurrence of timedependent inactivation of the 4-AP-sensitive current component. Current through homomeric channels formed by Kv3.1b subunits usually exhibits a sustained "delayed-rectifier" current with little time-dependent inactivation (Luneau et al., 1991; Grissmer, 1992, 1994; Weiser et al., 1994). Only channels including Kv3.3 and Kv3.4 subunits possess relatively fast time-dependent inactivation (Vega-Saenz de Miera et al., 1994; Weiser et al., 1994). A possible explanation for the present observation is that a fraction of the $\mathrm{Kv} 3.1 \mathrm{~b}$ subunits is in heteromultimers with other members of the Kv3 subfamily in parvalbumin-containing interneurons. In support of this hypothesis, in situ hybridization studies of the distribution of Kv3-subfamily members within the hippocampus have revealed a considerable overlap of Kv3.1b mRNA expression with that of Kv3.3, but not Kv3.2 or Kv3.4 (Weiser et al., 1994). A direct demonstration of the presence of $\mathrm{Kv} 3.1 \mathrm{~b}$ and $\mathrm{Kv} 3.3$ in these inhibitory neurons has not been possible because of the lack of 
Figure 9. 4-AP does not affect the sustained current in cclls shown to be Kv3.1b-negative by post hoc immunohistochemistry. $A$, Voltage-dependent activation curves were constructed for cells subsequently shown to be Kv3.1b-negative. The outward currents in these cells possessed a half-activation (Vhalf) at $+7.7 \pm 1.3 \mathrm{mV}(n=8) . B$, At a test potential of $+40 \mathrm{mV}$, addition of 4 -AP $(100 \mu \mathrm{M})$ had no effect on the sustained current component in a Kv3.1b-negative cell. Four traces are shown for both control and 4-AP, $C$, In an interneuron held under current-clamp conditions, 4-AP $(10-50$ $\mu \mathrm{M}$, arrows) had a minimal effect on the repolarization phase of the spontaneous action potentials. At a concentration of 50 $\mu \mathrm{M}$, the action-potential repolarization is $120 \%$ of control.
A.

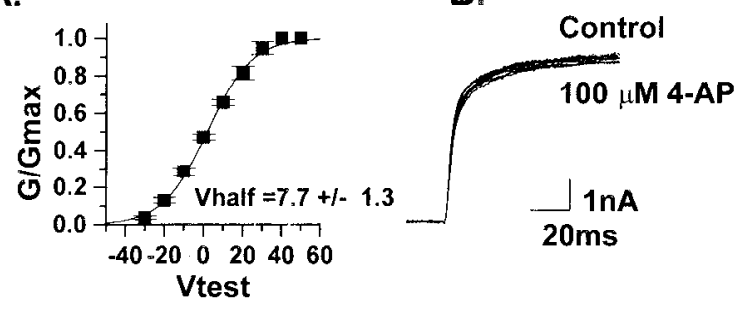

c.

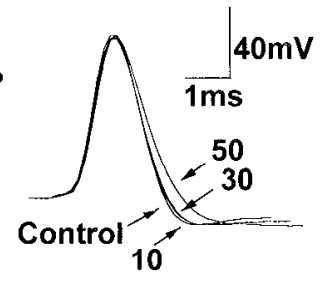

antibodies for Kv3.3. Alternatively, the current phenotype observed may be caused merely by the temporal overlap of homomeric Kv3.1 channels and other Kv3-subunit homomeric channels. Because all members possess similar pharmacological and voltage-dependent activation properties, this made the isolation of these potential current components difficult in the present experiments.

Consideration of some technical issues also may help explain the apparent inactivation of the 4-AP-sensitive current component. One possibility is that 4-AP, in addition to the block of current through Kv3.1 channels, blocks a contaminating transient current component also present in these cells. However, in st. oriens-alveus interneurons that do not express the Kv3.1 subunit, the transient current component removed by 4-AP had a higher $\mathrm{IC}_{50}(1.8 \mathrm{~mm})$, although the sustained current component in these cells was blocked by $<10 \%$ at concentrations up to $10 \mathrm{~mm} 4-\mathrm{AP}$ (Zhang and McBain, 1995a). Another mechanism that may underlie the observed current inactivation arises from the observation that homomeric channels formed from several Kv3 subunits display a decline in their conductance at positive potentials. This attenuation is attributable to a block of the ion-permeation pathway by some intracellular component, possibly $\mathrm{Mg}^{2+}$ (Rudy et al., 1991; Rettig et al., 1992; Vega-Saenz de Miera et al., 1992, 1994). In the present experiments, $\mathrm{Mg}^{2+}$ was omitted from the intracellular solution, making block by this ion an unlikely mechanism to explain the inactivating current phenotype observed.

In the present study, we provide evidence that channels containing the Kv3.1b subunit are responsible in part for repolarization at the peak of the action potential of the parvalbumincontaining cells of st. pyramidale. Experiments using currentclamp techniques demonstrate that low concentrations of 4-AP that may block Kv3.1b selectively affect the early phase of spike repolarization concomitant with an augmentation of the actionpotential amplitude. The increase in spike amplitude suggests that under control conditions the action potential usually is attenuated by the onset of outward current, presumably through Kv3.1bcontaining $\mathrm{K}^{+}$channels. Parvalbumin-containing interneurons belong to the class of fast-spiking interneurons that possess action potentials with an extremely short duration (Kawaguchi et al., 1987). In the present experiments, the peak of the action potential was close to $+30 \mathrm{mV}$ and occurred at $\sim 1.5 \mathrm{msec}$. At this time point, current through the 4-AP-sensitive current had reached $\sim 70 \%$ of its maximum at a test potential of $+40 \mathrm{mV}$, suggesting that a considerable number of Kv3.1-containing channels will be available during a single action potential. In addition, the rapid deactivation of the Kv3.1b current, as shown by tail-current analysis, predicts that its role will be restricted temporally, presumably to the initial phase of spike repolarization, which is consistent with the lack of effect of low concentrations of 4-AP on other actionpotential components or on the firing pattern of these cells.
For some time, the developmental onset of parvalbumin immunoreactivity in the cells has been associated with the acquisition of their fast-spiking characteristics (Kawaguchi et al., 1987; Bergmann et al., 1991). In the present study, however, we have demonstrated that the onset of expression of $\mathrm{Kv} 3.1 \mathrm{~b}$ is coincident with acquisition of parvalbumin immunoreactivity, This suggests that the fast-spiking activity of these interneurons is not determined by the onset of parvalbumin immunoreactivity per se, as previously thought; instead, it may be determined by the onset of $\mathrm{Kv} 3.1 \mathrm{~b}$ expression, a channel that may have a direct involvement in the determination of the action-potential characteristics in these cells. The observation that the Kv3.1 subunit is expressed preferentially in many cells known to be GABAergic and to possess high firing rates (Perney et al., 1992; Rudy et al., 1992; Lenz et al., 1994; Weiser et al., 1994, 1995) likely is not coincidental. The activation of Kv3.1 channels may act to keep the action potential short. In addition, the calcium-binding protein parvalbumin may buffer the intracellular calcium concentration. Both factors may act to prevent the accumulation of $\mathrm{Ca}^{2+}$ and the activation of $\mathrm{Ca}^{2+}$. activated outward currents. Furthermore, the rapid deactivation of Kv3.1 channels will help decrease the membrane conductance soon after the peak of the spike. These electrical properties of these neurons, taken together, will ensure a high frequency of action-potential firing. More likely, the observation that Kv3.1bcontaining chamnels help to shape the action potential of fastspiking interneurons also will extend to action potentials of other cells strongly expressing Kv3.1b or other Kv3-related subunits.

In conclusion, these experiments demonstrate that Kv3.1b subunits are expressed preferentially in parvalbumin-containing interneurons. The subcellular localization of the Kv3.1b subunit protein in the soma, proximal dendrites, and axons of these cells indicates that channels formed by this subunit may have a highly specific role in interneuronal physiology. Electrophysiological experiments have confirmed this prediction and provide evidence that currents through channels formed by Kv3.1b can be detected in these cells and have a role in determining their fast-spiking characteristics. These data strengthen the hypothesis that the specific functional roles of each hippocampal inhibitory-neuron population depend not only on the anatomical location of these cells but also on the complement of voltage " and ligand-gated channels expressed on a particular cell type.

\section{REFERENCES}

Aldrich RW, Getting PA, Thompson SH (1979) Inactivation of delayed outward current in molluscan neurone somata. J Physiol (Lond) 291:507--530.

Amaral DG, Kurz J (1985) The time of origin of cells demonstrating glutamic acid decarboxylase-like immunoreactivity in the hippocampal formation of the rat. Neurosci Lett 59:33-39. 
Bakst I, Morrison JH, Amaral DG (1985) The distribution of somatostatin-like immunoreactivity in the monkey hippocampal formation. J Comp Neurol 236:423-442。

Bayer SA (1980a) Development of the hippocampal region in the rat. I. Neurogenesis examined with $\left[{ }^{3} \mathrm{H}\right]$ thymidine autoradiography. $\mathrm{J}$ Comp Neurol 190:87-114.

Bayer SA (1980b) Development of the hippocampal region in the rat. II. Morphogenesis during embryonic and early postnatal life. J Comp Neurol 190:115-134.

Bergmann I, Nitsch R, Frotscher M (1991) Area-specific morphological and neurochemical maturation of non-pyramidal neurons in the rat hippocampus as revealed by parvalbumin immunocylochemistry. Anat Embryol 184:403-409.

Blanton MG, LoTurco JJ, Kriegstein AR (1989) Whole-cell recording from neurons in slices of reptilian and mammalian cerebral cortex. J Neurosci Methods 30:203-210.

Buhl EH, Halasy K, Somogyi P (1994a) Diverse sources of hippocampal unitary inhibitory postsynaptic potentials and the number of synaptic release sites. Nature 368:823-828.

Buhl EH, Han ZS, Lorinczi Z, Stezhka VV, Karnup SV, Somogyi P (1994b) Physiological properties of anatomically identified axo-axonic cells in the rat hippocampus. J Neurophysiol 71:1289-1307.

Chandy $\mathrm{KG}$, Douglas J, Gutman GA, Jan L, Joho R, Kaczmarek L, McKinnon D, North RA, Numa S, Philipson L, Rivera AB, Rudy B, Salkoff L, Swanson RA, Steiner D, Tanouye M, Tempel BL (1991) Simplified gene nomenclature (Abstr). Nature 352:26A.

Drewe JA, Verma S, Frech G, Joho RH (1992) Distinct spatial and temporal expression patterns of $\mathrm{K}^{+}$-channel mRNAs from different subfamilies. J Neurosci 12:538-548.

Edwards FA, Konnerth A, Sakmann B, Takahashi T (1989) A thin slice preparation for patch clamp recordings from synaptically connected neurones of the mammalian central nervous system. Pflïgers Arch 414:600-612.

Gahwiler BH, Llano I (1989) Sodium and potassium conductances in somatic membranes of rat Purkinje cells from organotypic cerebellar cultures. J Physiol (Lond) 417:105-122.

Grissmer S, Ghanshani S, Dethlefs B, McPherson JD, Wasmuth JJ, Gutman GA, Cahalan MD, Chandy KG (1992) The Shaw-related potassium channel gene, Kv3.1, on human chromosome 11 encodes the Type-1 $\mathrm{K}^{+}$channel in T cells. J Biol Chem 267:20971-20979.

Grissmer S, Nguyen AN, Aiyar J, Hanson DC, Mather RJ, Gutman GA, Karmilowicz MJ, Auperin DD, Chandy KG (1994) Pharmacological characterization of five cloned voltage-gated $\mathrm{K}^{+}$channels, types Kv1.1, $1.2,1.3,1.5$, and 3.1 , stably expressed in mammalian cell lines. Mol Pharmacol 45:1227-1234.

Gulyas AI, Miettinen R, Jacobowitz DM, Freund TF (1992) Calretinin is present in nonpyramidal cells of the hippocampus. I. A new type of neuron specifically associated with the mossy fibre system. Neuroscience $48: 1-27$.

Gutman GA, Chandy KG (1995) Voltage-gated $\mathrm{K}^{+}$channels (North RA, ed). Boca Raton, FL: CRC.

Halliwell JV (1990) $\mathrm{K}^{+}$channels in the central nervous system. Chichester: Ellis Horwood.

Hamill OP, Marty A, Neher E, Sakmann B, Sigworth FJ (1981) Improved patch-clamp techniques for high resolution current recording from cells and cell-free patches. PHügers Arch 391:85-100.

Jan LY, Jan YN (1990) How might the diversity of potassium channels be generated? Trends Neurosci 13:415-419.

Katsumaru H, Kosaka T, Heizmann CW, Hama K (1988) Immunocytochemical study of GABAergic neurons containing the calcium-binding protein parvalbumin in the rat hippocampus. Exp Brain Res $72: 347-362$

Kawaguchi Y, Katsumaru H, Kosaka T, Heizmann CW, Hama K (1987) Fast spiking cells in the rat hippocampus (CA1 region) contain the calcium-binding protein parvalbumin. Brain Res 416:369-374.

Kirsch GE, Drewe JA (1993) Gating-dependent mechanism of 4-aminopyridine block in two related potassium channels. J Gen Physiol 102:797-816.

Kohler C, Chan-Palay V (1982) Somatostatin-like immunoreactive neurons in the hippocampus: an immunocytochemical study in the rat. Neurosci Lett 34:259-264.

Kosaka T, Katsumaru H, Hama K, Wu JY, Heizmann CW (1987) GABAergic neurons containing the $\mathrm{Ca}^{2+}$ binding protein parvalbumin in the rat hippocampus and dentate gyrus. Brain Res 419:119-130.
Kues WA, Wunder F (1992) IIeterologous expression pattcrns of mammalian potassium-channel genes in developing and adult rat brain Eur J Neurosci 4:1296-1308.

Lacaille JC, Kunkel DD, Schwartzkroin PA (1989) Electrophysiological and morphological characterization of hippocampal interneurons. In: The hippocampus-new vistas (Chan-Palay V, Kohler C, eds), pp 285303. New York: Liss.

Lenz S, Perney TM, Qin Y, Robbins E, Chesselet MF (1994) GABAergic interneurons of striatum express the Shaw-like potassium channel Kv3.1. Synapse 18:55-66.

Lubbers K, Wolff JR, Frotscher M (1985) Neurogenesis of GABAergic Ileurons in the dentate gyrus: a combined autoradiographic and immunocytochemical study. Neurosci Lett 62:317-322.

Luneau CJ, Williams JB, Marshall J, Levitan ES, Oliva C, Smith JS, Antanavage J, Folander K, Stein RB, Swanson R, Kaczmarek L, Buhrow SA (1991) Alternative splicing contributes to the generation of $\mathrm{K}$ channel diversity in the mammalian central nervous system. Proc Nat Acad Sci USA 88:3932-3936.

McBain CJ (1994) Hippocampal inhibitory neuron activity in the elevated potassium model of epilepsy. J Neurophysiol 72:2853-2863.

McBain CJ, DiChiara TJ, Kauer JA (1994) Activation of metabotropic glutamate receptors differentially affects two classes of hippocampal interneurons and potentiates excitatory symaptic tramsmission. J Neurosci $14: 4433-4445$

Moreno H, Kentros C, Bueno E, Wesier M, Hernandez A, Vega-Saenz de Miera E, Ponce A, Thornhill W, Rudy B (1995) Thalamocortical projections have a $\mathrm{K}^{+}$channel that is phosphorylated and modulated by cAMP-dependent protein kinase. J Neurosci 15:5486--5501.

Morrison JH, Benoit R, Magistretti PJ, Bloom FE (1983) Immunocytochemical distribution of prosomatostatin-related peptides in cerebral cortex. Brain Res 262:344 351.

Nitsch R, Bergmann I, Kuppers K, Mueller G, Frotscher M (1990a) Late appearance of parvalbumin-immunoreactivity in the development of GABAergic neurons in the rat hippocampus. Neurosci Lett 118:147-150.

Nitsch R, Soriano E, Frotscher M (1990b) The parvalbumincontaining nonpyramidal neurons in the rat hippocampus. Anat Embryol 181:413-425.

Nunzi MG, Gorio A, Milan F, Freund TF, Somogyi P, Smith AD (1985) Cholecystokinin-immunoreactive cells form symmetrical synaptic contacts with pyramidal and non-pyramidal neurons in the hippocampus. $J$ Comp Neurol 237:485-505.

Perney TM, Marshall J, Martin KA, Hockfield S, Kaczmarek LK (1992) Expression of the mRNA for the Kv3.1 potassium channel gene in the adult and developing rat brain. $J$ Neurophysiol 68:756-766.

Pongs O (1992) Molecular biology of voltage-dependent potassium channels. Physiol Rev [Suppl] 72:S79-S88.

Rettig J, Wunder F, Stocker M, Lichtinghagen R, Mastiaux F, Beckh S, Kues W, Pedarzani P, Schroter KH, Ruppersberg JP, Veh R, Pongs O (1992) Characterization of a Shaw-related potassium channel family in rat brain. EMBO J 11:2473-2486.

Rudy B (1988) Diversity and ubiquity of $\mathrm{K}$ channels. Neuroscience 25:729-749.

Rudy B, Kentros C, Weiser M, Fruhling D, Serodio P, Vega-Saenz de Miera E, Ellisman MH, Pollock JA, Baker H (1992) Region-specific expression of a $\mathrm{K}^{-+}$channel gene in brain. Proc Natl Acad Sci. USA 89:4603-4607.

Rudy B, Sen K, Vega-Saenz de Miera E, Lau D, Ried T, Ward DC (1991) Cloning of a human cDNA expressing a high voltage-activating, TEAsensitive, type-A $\mathrm{K}^{+}$channel gene which maps to chromosome 1 band p21. J Neurosci Res 29:401-412.

Schlander M, Hoyer S, Frotscher M (1988) Glutamate decarboxylaseimmunoreactive neurons in the aging rat hippocampus are more resistant to ischemia than CA1 pyramidal cclls. Ncurosci Lctt $91: 241-246$.

Seress L, Frotscher M, Ribak CE (1989) Local circuit neurons in both the dentate gyrus and Ammon's horn establish synaptic connections with principal neurons in five day old rats: a morphological basis for inhibition in early development. Exp Brain Res 78:1-9.

Sheng M, Tsaur ML, Jan YN, Jan LY (1992) Subcellular segregation of two A-type $\mathrm{K}^{+}$channel proteins in rat central neurons. Neuron 9:271-284.

Sloviter RS (1989) Calcium binding protein (Calbindin-D28k) and parvalbumin immunocytochemistry: localization in the rat hippocampus 
with specific reference to the sclective vulncrability of hippocampal neurons to seizure activity. J Comp Neurol 280:183-196.

Soriano E, Cobas A, Fairen A (1989) Neurogenesis of glutamic acid decarboxylase immunoreactive cells in the hippocampus of mouse. $\mathrm{J}$ Comp Neurol 281:586-602.

Taglialatela M, Vandongen AMJ, Drewe JA, Joho RH, Brown AM, Kirsch GE (1991) Patterns of internal and external tetraethylammonium block in four homologous $\mathrm{K}^{+}$channels. Mol Pharmacol 40:299-307.

Tortosa A, Ferrer I (1993) Parvalbumin immunoreactivity in the hippocampus of the gerbil after transient forebrain ischemia: a qualitative and quantitative sequential study. Neuroscience 55:33-43.

Traub RD, Miles R (1991) Neuronal networks of the hippocampus. Cambridge: Cambridge UP.

Van der Zec EA, Luiten PGM (1993) GABAcrgic ncurons of the rat dorsal hippocampus express muscarinic acetylcholine receptors. Brain Res Bull 32:601-609.

Vega-Saenz de Miera E, Moreno H, Fruhling D, Kentros C, Rudy B (1992) Cloning of ShIII (Shaw-like) cDNAs encoding a novel highvoltage-activating, TEA-sensitive, type-A $\mathrm{K}^{+}$channel. Proc $\mathbf{R}$ Soc Lond [Biol] 248:9-18.
Vega-Sacnz de Micra E, Weiscr M, Kentros C, Lau D, Morcno II, Serodio P, Rudy B (1994) Shaw-related $\mathrm{K}^{+}$channels in mammals. In: Handbook of membrane channels, pp 41-78. New York: Academic.

Weiser M, Bueno E, Sekirnjak C, Martone ME, Baker H, Hillman D, Chen S, Thornhill W, Rudy B (1995) The potassium channel subunit Kv3.1b is localized to somatic and axonal membranes of specific populations of central nervous system neurons. J Neurosci 15:4298-4314.

Weiser M, Vega-Saenz de Miera E, Kentros C, Moreno H, Franzen L, Hillman D, Baker H, Rudy B (1994) Differential expression of Shawrelated channels in the rat central nervous system. J Neurosci 14:949-972.

Yokoyama S, Imoto K, Kawamura T, Higashida $H$, Iwabe N, Miyata T, Numa S (1989) Potassium channels from NG108-15 neuroblastomaglioma hybrid cells: primary structure and functional expression from cDNAs. FEBS Lett 259:37-42.

Zhang L, McBain CJ (1995a) Voltage-gated potassium currents in stratum oriens-alveus inhibitory neurones of the rat CA1 hippocampus. J Physiol (Lond) 488:647-660.

Zhang L, McBain CJ (1995b) Potassium conductances underlying action potential repolarization and afterhyperpolarization in rat CA1 hippocampal interneurones. J Physiol (Lond) 488:661-672. 